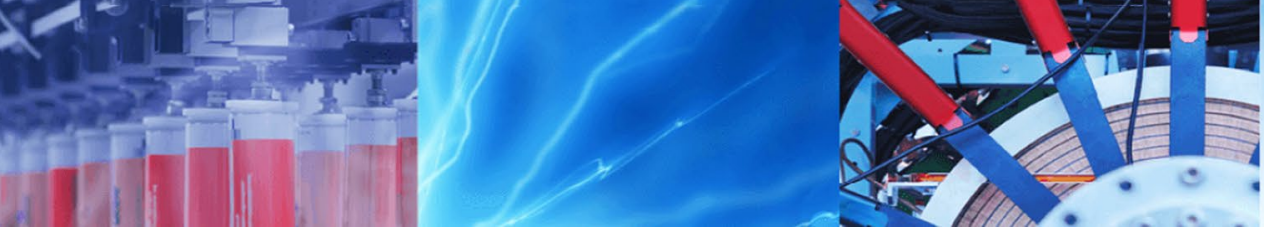

Research Article

\title{
As(III) and As(V) remediation in an aqueous medium using a cellulosic biosorbent: kinetics, equilibrium, and thermodynamics study
}

\author{
Moonmoon Choudhary ${ }^{1}$ [D $\cdot$ Krishna Gopal Bhattacharyya ${ }^{2}$
}

Received: 9 April 2020 / Accepted: 24 August 2020 / Published online: 9 September 2020

(c) Springer Nature Switzerland AG 2020

\begin{abstract}
Arsenic is an element of concern, as it is widely distributed in the environment and poses a great threat to the health of humans and other living beings. The present study investigates the uptake of arsenite $(\mathrm{As}(\mathrm{III}))$ and arsenate $(\mathrm{As}(\mathrm{V}))$ ions from aqueous solution using low-cost Polyalthia longifolia leaf powder (PLP). The low-cost adsorbent was characterized by FTIR and SEM-EDX measurements. Adsorption experiments were carried out, with contact time, $\mathrm{pH}$, adsorbent amount, the concentration of $\mathrm{As}(\mathrm{III})$ and $\mathrm{As}(\mathrm{V})$ and co-existing anions $\left(\mathrm{PO}_{4}{ }^{3-}\right.$ and $\left.\mathrm{BO}_{3}{ }^{3-}\right)$ as the variables. Maximum adsorption of $\mathrm{As}(\mathrm{III})$ and $\mathrm{As}(\mathrm{V})$ was found at $\mathrm{pH} 7.5$ and 3.0, respectively. The presence of $\mathrm{PO}_{4}{ }^{3-}$ and $\mathrm{BO}_{3}{ }^{3-}$ was found to be sufficient for the uptake of $\mathrm{As}(\mathrm{III})$ and $\mathrm{As}(\mathrm{V})$, respectively. Adsorption of both $\mathrm{As}(\mathrm{III})$ and $\mathrm{As}(\mathrm{V})$ on PLP was found to follow the pseudo-second-order kinetic model. Freundlich, Langmuir, and Temkin models of adsorption were tested for adsorption of $\mathrm{As}(\mathrm{III})$ and $\mathrm{As}(\mathrm{V})$ on PLP, and the results indicated that adsorption data closely followed the Langmuir model. The maximum adsorption capacity for $\mathrm{As}(\mathrm{III})$ and $\mathrm{As}(\mathrm{V})$ was $1.76 \mathrm{mg} \mathrm{g}^{-1}$ and $1.87 \mathrm{mg} \mathrm{g}^{-1}$, respectively, under the experimental conditions. Thermodynamic analysis showed that the process of adsorption of both $\mathrm{As}(\mathrm{III})$ and $\mathrm{As}(\mathrm{V})$ on PLP was spontaneous and exothermic with decreasing degrees of freedom. The results indicated that PLP-As(III) and $\operatorname{PLP}-\mathrm{As}(\mathrm{V})$ interaction equilibria were efficient and therefore could be explored for practical applications.
\end{abstract}

Keywords Adsorption $\cdot$ Polyalthia longifolia $\cdot \operatorname{As}($ III $) \cdot \operatorname{As}(\mathrm{V})$

\section{Introduction}

Creating one of the largest pollution problems in the world's history, arsenic (As) is recognized as a Class A human carcinogen by the US Environmental Protection Agency $[1,2]$. The present-day scenario is that many developed and developing countries have reported arsenic contamination, with southern and southeastern Asia being the most heavily affected. The river valleys of the GangaMeghna-Brahmaputra river system in India and Bangladesh, the Indus River in Pakistan, the Red River in Vietnam, the Irrawaddy River in Myanmar, the Yellow River in China, and the Mekong River in Laos and Cambodia have been reported to have elevated concentrations of As [3].
Arsenic pollution is induced in the environment by both natural and anthropogenic sources, including weathering reactions, volcanic eruptions, biological activity, use of arsenical pesticides and fertilizers, industrial waste discharge, mining, discharge from coal-fired thermal power plants, petroleum refining, and ceramic industries $[4,5]$.

Arsenic is found in both organic and inorganic form in nature, but inorganic As compounds are known to be 100 times more poisonous than organic As compounds [6]. The oxidation states of inorganic arsenic (i-As) in natural water depends on the environmental conditions. In surface water, under an aerobic and oxidized environment, $\mathrm{As}(\mathrm{V})$ is stable as monovalent $\left(\mathrm{H}_{2} \mathrm{AsO}_{4}{ }^{-}\right)$and divalent $\left(\mathrm{HAsO}_{4}{ }^{2-}\right)$ oxy-anions. However, groundwater under anaerobic and

Moonmoon Choudhary, moonschem@gmail.com | 'Department of Chemistry, Gauhati University, Guwahati, Assam 781014, India. ${ }^{2}$ Present Address: Department of Chemistry, Assam Don Bosco University, Tapesia Gardens, Sonapur, Assam 782402, India. 
reduced conditions is dominated by $\mathrm{As}$ (III) in the form of the uncharged $\mathrm{H}_{3} \mathrm{AsO}_{3}$ [4]. The toxicity of As is largely dependent on its chemical form. As(III) is more soluble, toxic, and mobile than $\mathrm{As}(\mathrm{V})$. This is due to a lack of electrostatic attraction in $\mathrm{As}(\mathrm{III})$, whereas $\mathrm{As}(\mathrm{V})$ is adsorbed more strongly on the particle surface to form thermodynamically stable surface complexes with a variety of oxides [5].

It is the inorganic arsenic (i-As) which is primarily responsible for cancer in different organs, arsenicosis, skin lesions, and cardiovascular diseases [7]. As(III) has a higher affinity for proteins than As(V). Research has shown that As cannot be excreted from the human body, where it binds with sulfhydryl groups in proteins and accumulates in tissues with high keratin content (skin, hair, and nails) $[8,9]$. It has been reported that i-As is also capable of crossing the placental membrane and may affect the unborn baby [10]. Arsenic also appears in human milk at low concentrations [11]. Because of the widespread negative impact of ubiquitous arsenic on human health, the World Health Organization (WHO), US Environmental Protection Agency (EPA), and the European Commission lowered the maximum permissible arsenic content in drinking water from $50 \mu \mathrm{g} \mathrm{L}^{-1}$ to $10 \mu \mathrm{g} \mathrm{L}^{-1}[12,13]$.

Arsenic decontamination of water has received serious attention from researchers over the past decade, as it has become necessary to remove arsenic from water in order to protect aquatic and terrestrial life. Methods of arsenic removal include chemical precipitation, oxidation and filtration, ion exchange, reverse osmosis, and adsorption and membrane technology. These methods involve high energy input, complicated procedures, and production of a large amount of toxic sludge. Adsorption is considered superior to other methods for the removal of dissolved arsenic, as it is found to be costeffective, sludge-free, renewable, and technologically simple. For any method to be universal, it should rely on facile technology for installation by small communities [14]. Most problems arise in terms of the cost and efficiency of the adsorbent. In this regard, biosorption (adsorption using biomaterials) has gained popularity due its to cost-effectiveness, eco-friendly nature, and abundant availability, especially in a developing country like India. A wide range of raw biomaterials and their modified forms have recently been employed as adsorbents for the removal of metal/non-metal ions, dyes, or other contaminants present in water [15-21]. For example, agricultural waste, waste biomass, and other biological resources have been investigated for this purpose. These include Moringa oleifera (Lamarck) seed powder [22], fish scale, chicken fat and coconut fiber [23], rice polish [24], green algae (Ulothrix cylindricum) biomass
[25], Momordica charantia biomass [26], lichen (Xanthoria parietina) biomass [27], green algae (Maugeotia genuflexa) [28], long-root Eichhornia crassipes [29], the stem of Acacia nilotica [30], the biomass of marine macrophytes [31], pine leaves [32], palm bark biomass [33], Hydrilla verticillata [34], pulp/sludge of flowers such as Hibiscus rosa-sinensis, Rosa rosa, Tagetes erecta, and Canna indica [35], polyethylenimine-modified Zea mays [36], Leucaena Leucocephala seed powder [37], Arthrobacter spp. biomass [38], multi-amino-functionalized cellulose [39], Saccharum officinarum (sugarcane) bagasse [40], and neem (Azadirachta indica) bark [41].

Plant leaves are rich in cellulose, and several studies have revealed that cellulose can adsorb metal ions [42]. However, very few studies have reported the use of plant leaves for the uptake of $\mathrm{As}(\mathrm{III})$ and $\mathrm{As}(\mathrm{V})$ from aqueous solution. The present study investigates the use of the Polyalthia longifolia leaf powder (PLP) as a bioadsorbent for the removal of aqueous arsenic anions. Polyalthia longifolia trees are abundantly available in tropical and subtropical regions. Many significant medicinal properties (including anti-cancer properties) of Polyalthia longifolia have been reported [43-48]. Because of its excellent availability, low toxicity, and low cost, PLP has been explored for the elimination of aqueous arsenic. Natural water may, however, contain a host of anions along with $\mathrm{As}(\mathrm{III})$ and $\mathrm{As}(\mathrm{V})$. Among these anions, the influence of phosphate and borate ions could be interesting, as both are trivalent anions similar to As(III), and therefore the influence of these anions on arsenic adsorption is also investigated. It is known that arsenic is a chemical analogue of phosphorus, sharing the same outer shell configuration of $\mathrm{s}^{2} \mathrm{p}^{3}$, so they exhibit similar chemical properties and are likely to compete with each other for sorption. The metalloid arsenic also exhibits many similarities to its diagonal neighbor boron. Therefore, the influence, if any, of phosphate and borate on the adsorption of $\mathrm{As}(\mathrm{III})$ and $\mathrm{As}(\mathrm{V})$ is also investigated in this work.

Thus, the main objective of the present study was to investigate the biomaterial obtained from leaves of Polyalthia longifolia as a suitable alternative arsenic adsorbent in aqueous solution. Fourier transform infrared spectroscopy (FTIR) and scanning electron microscopy/energy-dispersive X-ray spectroscopy (SEM-EDX) measurements were utilized for characterization of the functional groups and surface morphology of the adsorbent, and also to explain the interactions of PLP with $\mathrm{As}(\mathrm{III})$ and $\mathrm{As}(\mathrm{V})$. Optimum experimental conditions were determined with respect to $\mathrm{pH}$, interaction time, adsorbent loading, temperature of interaction, and presence of other anions. The experimental data were subjected to different adsorption and kinetics models. 


\section{Materials and methods}

\subsection{Preparation of biosorbent}

Mature leaves of Polyalthia longifolia were collected from Gauhati University (Assam, India) campus. The leaves were thoroughly washed to remove dust and other impurities, and were then sun-dried followed by drying in an airoven at a temperature $\leq 343 \mathrm{~K}$ for several hours until they became crisp. The leaves were then converted to powder form by crushing them in a grinder followed by washing several times until the washes were colorless. This ensured that the powder was free of plant pigments and soluble substances which might interfere with the adsorption measurements. The washed leaf powder was further dried in the air-oven for several hours at $343 \mathrm{~K}$ until the water was completely removed. Lumps were ground in a mortar, and the powder retained between $75 \mu \mathrm{m}$ and $63 \mu \mathrm{m}$ sieves was preserved as the biosorbent containing particles of almost uniform size. The biosorbent Polyalthia longifolia leaf powder (PLP) was kept in clean plastic containers and stored in a desiccator.

\subsection{Characterization of the biosorbent}

Arsenic-loaded and unloaded PLP were characterized with FTIR spectra using a KBr pellet technique (IRAffinity-1 Fourier Transform Infrared Spectrophotometer, Shimadzu, range $4000-400 \mathrm{~cm}^{-1}$ ).

Raw PLP and As(III)- and As(V)-loaded PLP were dried in an oven at a temperature less than $343 \mathrm{~K}$. Degassing preceded by gold-coating of the samples was used to prepare the samples for surface morphology study using a scanning electron microscope (SEM) coupled with EDX (ZEISS Sigma 300; resolution $1 \mathrm{~nm}$ at a working distance of less than $6 \mathrm{~mm}$, accelerating voltage $0.2-30 \mathrm{kV}$ ) at the Department of Chemistry, Gauhati University, Guwahati, India.

The electrostatic interactions between biosorbent particle surfaces and arsenic anions result in developing an electrical potential in the solid-liquid interface, expressed in terms of zeta potential. The charge distribution at the liquid-solid interface is controlled by the $\mathrm{pH}$ of the solution. The surface charge characteristics of PLP at different
$\mathrm{pH}$ values $(\mathrm{pH}=1-10)$ were determined from the zeta potential measurements using a Zetasizer Nano ZS90 (Malvern Instruments) at IASST, Guwahati.

\subsection{Preparation of As(III) solution}

Stock solutions of arsenite $\left(\mathrm{As}^{3+}\right)$ and arsenate $\left(\mathrm{As}^{5+}\right)$ of concentration $1000 \mathrm{mg} \mathrm{L}^{-1}$ were prepared by dissolving $1.7340 \mathrm{~g}$ of $\mathrm{NaAsO}_{2}$ (Merck, Mumbai) and $4.1634 \mathrm{~g}$ of $\mathrm{Na}_{2} \mathrm{HAsO}_{4} .7 \mathrm{H}_{2} \mathrm{O}$ (Merck, Mumbai) in $1.0 \mathrm{~L}$ of doubledistilled water. Solutions of desired concentrations were prepared from these stock solutions in their natural $\mathrm{pH}$ by appropriate dilution with double-distilled water. The chemicals were used without further purification and were obtained as sealed from the chemical supplier.

\subsection{Adsorption experiments}

The adsorption experiments were carried out in $50 \mathrm{~mL}$ Erlenmeyer flasks. The amount of PLP taken in a flask was $20 \mathrm{mg}$, with $20 \mathrm{~mL}$ of aqueous arsenic(III) or (V) solution, i.e. an adsorbent loading of $1 \mathrm{~g} \mathrm{~L}^{-1}$ (except when PLP amount was varied). The mixture was agitated in a thermostatic water bath shaker for a pre-determined time interval. After the adsorption experiment, the mixture was filtered, and $\mathrm{As}(\mathrm{III})$ or $\mathrm{As}(\mathrm{V})$ remaining unadsorbed in the filtrate was determined with the help of an atomic absorption spectrophotometer (Agilent Technologies 200 Series AA, Model 240) using a hydride generation technique. All experiments were done in triplicate and the concurrent value was retained. Before the actual experiments, sets of blank experiments were carried out to determine whether there was any adsorption on the walls of the container. These experiments showed no measurable outcome. The batch adsorption experiments were conducted under different conditions as mentioned in Table 1. The amount of arsenic adsorbed per unit mass of the adsorbent and the percentage of adsorption were calculated using Eqs. 1 and 2 , respectively, as given below:

$q_{t}\left(\mathrm{mg} \mathrm{g}^{-1}\right)=\left(C_{o}-C_{t}\right) / m$

\%of adsorption $=\left[\left(C_{o}-C_{t}\right) / C_{o}\right] \times 100$,
Table 1 Experimental conditions for different sets of batch experiments
$\mathrm{pH}$

Interaction time (min)

Adsorbent amount $\left(\mathrm{g} \mathrm{L}^{-1}\right)$

As (III) or As(V) $\left(\mathrm{mg} \mathrm{L}^{-1}\right)$

Temperature $(K)$

Adsorbent particle size $(\mu \mathrm{m})$
$2.0,3.0,4.0,5.0,6.0,6.5,7.0,7.5,8.0,8.5,9.0,10.0$

$5,10,20,30,45,60,90,120,150,180,210,240$, $270,300,330,360$

$1.0,2.0,3.0,4.0,5.0$

$0.5,1.0,1.5,2.0,2.5,3.0,4.0,5.0$

$303,313,323$

63-75 
where $C_{o}$ and $C_{t}$ are the concentration of arsenic at the beginning and at time ' $t$ ' respectively. The amount of biosorbent used is given by ' $m$ '.

\subsection{Co-existing anions $\mathrm{PO}_{4}{ }^{3-}$ and $\mathrm{BO}_{3}{ }^{3-}$ in $\mathrm{As}(\mathrm{III}) /$ $\mathrm{As}(\mathrm{V})$ adsorption}

Stock solutions of phosphate and borate were prepared by dissolving $1.8340 \mathrm{~g}$ of $\mathrm{K}_{2} \mathrm{HPO}_{4}$ and $2.4566 \mathrm{~g}$ of $\mathrm{Na}_{2} \mathrm{~B}_{4} \mathrm{O}_{7} \cdot 10 \mathrm{H}_{2} \mathrm{O}$ in $1000 \mathrm{~mL}$ double-distilled water. From the stock solutions, phosphate and borate solutions of desired concentrations, viz., $0.5,2.5,5.0 \mathrm{mg} \mathrm{L}^{-1}$ were obtained. Arsenic solution $\left(\mathrm{As}^{3+}\right.$ and $\left.\mathrm{As}^{5+}\right)$ of strength $1.0 \mathrm{mg} \mathrm{L}^{-1}$ was also prepared. To analyze the effects of interfering ions equal volumes of arsenic $\left(\mathrm{As}^{3+}\right.$ or $\left.\mathrm{As}^{5+}\right)$ and interfering ion solution $\left(\mathrm{PO}_{4}{ }^{3-}\right.$ or $\left.\mathrm{BO}_{3}{ }^{3-}\right)$ were mixed with PLP $\left(1 \mathrm{~g} \mathrm{~L}^{-1}\right)$ at a temperature of $303 \mathrm{~K}$ and $\mathrm{pH}$ unadjusted. After completion of the reaction, the mixture was filtered, and arsenic in the filtrate was estimated.

\subsection{Adsorption kinetics}

Kinetic study is important in terms of reaction pathways and mechanisms of sorption interaction. Kinetics is also useful for industrial purposes in designing fixed-bed columns. The kinetic rate coefficients are related to the mass transfer coefficient and fluid phase concentration in a fixed-bed column. Adsorption is a multi-step process, and the rate of the adsorption process is determined by the slowest step. The adsorption rate processes were tested with the following well-known kinetic models to understand the possible mechanism.

The pseudo-first-order or Lagergren model is one of the most commonly used models [49] and is given by the equation:

$\log \left(q_{\mathrm{e}}-q_{\mathrm{t}}\right)=\log q_{\mathrm{e}}-k_{1} t / 2.303$,

which shows how the amount $q_{t}$ adsorbed per unit mass at time $t$ is related to the amount $q_{\mathrm{e}}$ adsorbed per unit mass at equilibrium; $k_{1}$ is the first-order rate coefficient. The values of $k_{1}$ and $q_{\mathrm{e}}$ were obtained from plots of $\log \left(q_{\mathrm{e}}\right.$ $\left.-q_{t}\right)$ vs. $t$. The test of validity can again be administered by comparing the experimental ' $q$ e' value with that obtained from the pseudo-first-order plots.

The pseudo-second-order model [49] is based on the well-known rate equation:

$t / q_{t}=1 /\left(k_{2} q_{\mathrm{e}}^{2}\right)+\left(1 / q_{\mathrm{e}}\right) t$,

where $q_{t}$ and $q_{\mathrm{e}}(\mathrm{mg} / \mathrm{g})$ are the amount of solute adsorbed per unit mass of PLP at time $t(\mathrm{~min})$ and at equilibrium, respectively, and $k_{2}$ is the second-order rate coefficient $\left(\mathrm{g} \mathrm{mg}^{-1} \mathrm{~min}^{-1}\right) \cdot k_{2}$ and $q_{\mathrm{e}}$ values are obtained from the slope and the intercept of the plots of $t / q_{t} v s$. $t$. The test of validity can again be administered by comparing the experimental ' $q_{\mathrm{e}}$ ' value with that obtained from the second-order plots. The second-order rate expression was used to describe interactions involving valence forces via sharing or exchange of electrons between the adsorbent and adsorbate as covalent forces, and ion exchange.

The intra-particle diffusion model [50] is given by the equation:

$q_{t}=k_{i} \cdot t^{0.5}$

where $k_{i}\left(\mathrm{mg} \mathrm{g}^{-1} \mathrm{~min}^{-0.5}\right)$ is the intra-particle diffusion rate coefficient. When this relation is valid, $k_{i}$ values under different conditions are calculated from the slopes of the straight-line portion of the plot. One significant feature of these plots is that they have zero intercept.

\subsection{Adsorption isotherm}

Adsorption isotherms give a quantitative distribution of metal ions between the liquid phase (solution) and the adsorbent phase (solid) under equilibrium conditions. In the present study, Langmuir, Freundlich, and Temkin isotherms were applied to the experimental data to interpret the experimental results. The Freundlich isotherm assumes the formation of several layers of adsorbate on the heterogeneous surface of the adsorbent with the non-equivalent surface sites [39]. The isotherm equation is:

$\log q_{\mathrm{e}}=(1 / n) \log C_{\mathrm{e}}+\log K_{f}$

where $C_{\mathrm{e}}$ is the equilibrium concentration of $\mathrm{As}(\mathrm{III})$ or $\mathrm{As}(\mathrm{V})$ $\left(\mathrm{mg} \mathrm{L}^{-1}\right), q_{\mathrm{e}}$ is the amount of the As(III) or As(V) adsorbed per unit mass $\left(\mathrm{mg} \mathrm{g}^{-1}\right)$, and $K_{f}\left(\mathrm{mg}^{1-1 / n} \mathrm{~L}^{1 / n} \mathrm{~g}^{-1}\right)$ and $\mathrm{n}$ are Freundlich coefficients related to adsorption capacity and adsorption intensity, respectively. It is generally accepted that the reciprocal Freundlich intensity $(1 / n)$ is $<1.0$ for favorable adsorption.

The Langmuir isotherm model is limited to the formation of a single layer of adsorbate on the adsorbent surface, with all the surface sites being considered as equivalent and no adsorbate-adsorbate interactions on the adsorbent surface [39]. The Langmuir isotherm equation is:

$C_{\mathrm{e}} / q_{\mathrm{e}}=\left(1 / b q_{m}\right)+\left(1 / q_{m}\right) C_{\mathrm{e}}$

where $q_{m}\left(\mathrm{mg} \mathrm{g}^{-1}\right)$ and $b\left(\mathrm{~L} \mathrm{mg}^{-1}\right)$ are Langmuir coefficients related to the monolayer adsorption capacity and adsorption equilibrium constant, respectively. In the Langmuir model, a dimensionless constant $R_{L}$ known as the separation factor for equilibrium parameter [39] is introduced as:

$R_{L}=1 /\left(1+b C_{o}\right)$, 
where $C_{o}$ is the initial concentration of $A s(I I I)$ or $A s(V)$ (in $\left.\mathrm{mg} \mathrm{L}^{-1}\right)$ and $b\left(\mathrm{~L} \mathrm{mg}^{-1}\right)$ is the Langmuir equilibrium constant. The value of $R_{L}$ indicates the type of isotherm, i.e. irreversible $\left(R_{L}=0\right)$, favorable $\left(0<R_{L}<1\right)$, linear $\left(R_{L}=1\right)$, or unfavorable $\left(R_{L}>1\right)$.

The Temkin isotherm is developed by taking into consideration the effects of adsorbate-adsorbate interactions. This isotherm assumes that (a) the heat of adsorption of all the adsorbate molecules/ions on the surface decreases linearly with coverage due to adsorbate-adsorbate interactions, and (b) adsorption is characterized by a uniform distribution of binding energies, up to some maximum binding energy [39]. The linear form of the Temkin isotherm is:

$q_{\mathrm{e}}=2.303 B \log k_{\mathrm{T}}+2.303 B \log C_{\mathrm{e}^{\prime}}$

with $k_{\mathrm{T}}\left(\mathrm{L} \mathrm{mg}^{-1}\right)$ being the Temkin isotherm constant and $b_{\mathrm{T}}\left(\mathrm{J} \mathrm{mol}^{-1}\right)$ the Temkin coefficient related to the heat of adsorption, $B$ a dimensionless constant such that $B=R_{T} / b_{T}$, $\mathrm{R}$ the gas constant $\left(8.314 \mathrm{~J} \mathrm{~mol}^{-1} \mathrm{~K}^{-1}\right)$, and $T$ the absolute temperature $(K)$ of adsorption.

\subsection{Thermodynamics of adsorption}

Adsorption is a surface phenomenon involving adsorbate-adsorbent interactions resulting in the binding of adsorbate molecules/ions to the adsorbent surface. Determining the strength of binding of a species to a solid surface is essential. This can be done by measuring the heat evolved or absorbed during the adsorption of a solute from the liquid phase to a solid surface. The thermodynamic parameters of entropy (S), enthalpy (H), and Gibbs energy (G) for the adsorption process are studied in this work. The changes in standard Gibbs energy $\left(\Delta G^{\circ}\right)[50]$ was calculated from the equation:

$\Delta G^{\circ}=-2.303 R T \log K$,

where $R$ is the universal gas constant $\left(8.314 \mathrm{~J} \mathrm{~mol}^{-1} \mathrm{~K}^{-1}\right)$, $T$ the temperature $(K)$, and $K\left(q_{\mathrm{e}} / C_{\mathrm{e}}\right)$ the equilibrium constant for adsorbate-adsorbent interaction. The standard enthalpy $\left(\Delta H^{\circ}\right)$ and standard entropy $\left(\Delta S^{\circ}\right)$ parameters were obtained from the classic van 't Hoff equation [40]:

$\log \left(q_{\mathrm{e}} / C_{\mathrm{e}}\right)=\Delta S^{\circ} /(2.303 R)-\Delta H^{\circ} /(2.303 \mathrm{RT})$,

where the ratio $q_{\mathrm{e}}\left(\mathrm{mg} \mathrm{g}^{-1}\right) / C_{\mathrm{e}}\left(\mathrm{mg} \mathrm{L}^{-1}\right)$ is known as the adsorption affinity.

\section{Results and discussion}

\subsection{Characterization of PLP}

FTIR measurements of the raw PLP and PLP after adsorption of $\mathrm{As}(\mathrm{III})$ and $\mathrm{As}(\mathrm{V})$ helped to identify the functional groups that are likely involved in binding of arsenic anions to the biosorbent surface (Fig. 1). The FTIR results are summarized in Table 2. The absorption bands at $3415 \mathrm{~cm}^{-1}, 3471 \mathrm{~cm}^{-1}$, and $3545 \mathrm{~cm}^{-1}$ correspond to the presence of hydroxyl $(-\mathrm{OH})$ and amine $(-\mathrm{NH})$ groups. However, the band is broader after adsorption of $\mathrm{As}(\mathrm{V})$, which may be due to the involvement of $-\mathrm{NH}$ groups [29]. Stretching vibrations at $2970 \mathrm{~cm}^{-1}, 2931 \mathrm{~cm}^{-1}$, $2858 \mathrm{~cm}^{-1}, 1462 \mathrm{~cm}^{-1}$, and $1373 \mathrm{~cm}^{-1}$ are due to $-\mathrm{CH}_{3}$ asymmetric stretching, $-\mathrm{CH}_{2}-$ asymmetric stretching, $-\mathrm{CH}_{2}-$ symmetric stretching, $-\mathrm{CH}_{3}$ asymmetric bending, and $-\mathrm{CH}_{3}$ symmetric bending vibrations, respectively. The $\mathrm{C}=\mathrm{O}$ stretching vibration at $1728 \mathrm{~cm}^{-1}$ shifted to $1712 \mathrm{~cm}^{-1}$ for As(III) and $1735 \mathrm{~cm}^{-1}$ for As(V) sorption [51]. The peak representing $\mathrm{C}-\mathrm{O}$ stretching of alcohol and carboxylic acid at $1051 \mathrm{~cm}^{-1}$ shifted to $1029 \mathrm{~cm}^{-1}$ and $1028 \mathrm{~cm}^{-1}$ for As(III) and As(V) treated biomass, respectively [52]. The sharp peak at $1562 \mathrm{~cm}^{-1}$ indicated $\mathrm{N}-\mathrm{H}$ bending vibrations in primary and secondary amines and amides [53]. A band at $1622 \mathrm{~cm}^{-1}$ represents the aromatic ring structure such as in the lignin aromatic group [40]. The FTIR peaks shifted from $1249 \mathrm{~cm}^{-1}$ to $1259 \mathrm{~cm}^{-1}$ and $1251 \mathrm{~cm}^{-1}$ for $\mathrm{As}(\mathrm{III})-$ and $\mathrm{As}(\mathrm{V})$-loaded PLP, respectively, thus suggesting a $C-N$ stretching vibration [54]. These results can be interpreted as due to the involvement of hydroxyl $(-\mathrm{OH})$, amine $(-\mathrm{NH})$, and

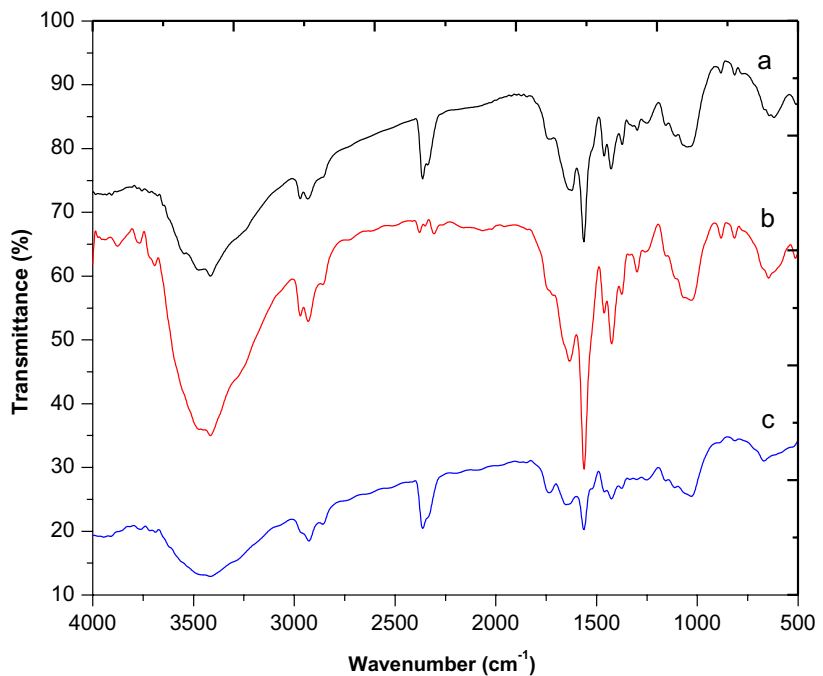

Fig. 1 FTIR spectra of PLP (a), As(III)-loaded PLP, (b) and As(V)loaded PLP (c) 
Table 2 Summary of IR bands found in the leaves of the Polyalthia longifolia spectrum before and after contact with $\mathrm{As}(\mathrm{III})$ or $\mathrm{As}(\mathrm{V})$ solution

\begin{tabular}{|c|c|c|c|c|}
\hline \multicolumn{3}{|c|}{ IR band frequency $\left(\mathrm{cm}^{-1}\right)$} & \multirow{2}{*}{$\begin{array}{l}\text { Functional group } \\
\text { assignment }\end{array}$} & \multirow[t]{2}{*}{ References } \\
\hline Raw PLP & $\begin{array}{l}\text { As(III)- } \\
\text { loaded } \\
\text { PLP }\end{array}$ & $\begin{array}{l}\text { As }(V)- \\
\text { loaded } \\
\text { PLP }\end{array}$ & & \\
\hline 3545 & - & - & \multirow{3}{*}{$\begin{array}{l}\mathrm{O}-\mathrm{H} \text { and } \mathrm{N}-\mathrm{H} \text { stretch- } \\
\text { ing }\end{array}$} & \multirow[t]{3}{*}{29} \\
\hline 3471 & 3471 & - & & \\
\hline 3415 & 3415 & 3415 & & \\
\hline 2970 & 2968 & 2962 & $\begin{array}{l}-\mathrm{CH}_{3} \text { asymmetric } \\
\text { stretching }\end{array}$ & 51 \\
\hline 2931 & 2929 & 2926 & $\begin{array}{l}-\mathrm{CH}_{2}-\text { asymmetric } \\
\text { stretching }\end{array}$ & 51 \\
\hline 2858 & 2858 & 2858 & $\begin{array}{l}-\mathrm{CH}_{2}-\text { symmetric } \\
\text { stretching }\end{array}$ & 51 \\
\hline 1728 & 1712 & 1735 & $\mathrm{C}=\mathrm{O}$ stretching & 51 \\
\hline 1622 & 1633 & 1651 & Aromatic ring structure & 40 \\
\hline 1562 & 1560 & 1562 & $\mathrm{~N}-\mathrm{H}$ bending & 53 \\
\hline 1462 & 1462 & 1460 & $\begin{array}{l}-\mathrm{CH}_{3} \text { asymmetric } \\
\text { bending }\end{array}$ & 51 \\
\hline 1373 & 1375 & 1375 & $\begin{array}{l}-\mathrm{CH}_{3} \text { symmetric bend- } \\
\text { ing }\end{array}$ & 51 \\
\hline 1249 & 1259 & 1251 & C-N stretching & 54 \\
\hline 1051 & 1029 & 1028 & $\mathrm{C}-\mathrm{O}$ stretching & 52 \\
\hline
\end{tabular}

carboxyl (-COOH) groups in binding $\mathrm{As}(\mathrm{III})$ and $\mathrm{As}(\mathrm{V})$ anions to the surface of PLP particles.

The SEM micrographs were taken at a resolution of $\times 20,000$ and operated at $5 \mathrm{kV}$ accelerating voltage. The micrograph of unloaded PLP reveals a rough surface with irregular cavities and highly broken edges on the surface. After adsorption of As(III) and As(V), the cavities and broken edges may have been filled with As(III) and $A s(V)$ ions, resulting in a comparatively smoother surface with decreased porosity as shown in Fig. 2a, c, e. The probability of arsenic anions, trapped and adsorbed into the pores of PLP, could be observed when the EDX spectra were analyzed. Native PLP consists mainly of $C$, $\mathrm{N}$, and $\mathrm{O}$, with some traces of $\mathrm{Ca}$. After adsorption, these and other peaks were reduced or enhanced, with a new peak of arsenic in the spectra becoming visible (Fig. 2b, $d, f)$.

A graphical representation of the surface charge of PLP at different $\mathrm{pH}$ values at $303 \mathrm{~K}$ is given in Fig. 3. The value of zeta potential decreased with increasing $\mathrm{pH}$ from 1 to 10. The point of zero charge ( $\mathrm{pzc} ; \mathrm{pH}$ value corresponding to zero zeta potential) was found to be 2.3. The surfaces of PLP particles were negatively charged at $\mathrm{pH}>$ pzc. Earlier it was shown that the pzc of the bioadsorbent Eichhornia crassipes was 1.9 [29], which is slightly lower than that in the case of PLP determined in this work.

\subsection{Adsorption experiments}

\subsubsection{Effects of $\mathrm{pH}$}

The $\mathrm{pH}$ is an important factor that greatly influences the adsorption process. In the present work, the $\mathrm{pH}$ was varied from 2.0 to 10.0 for the adsorbate-adsorbent mixture, with $1.0 \mathrm{~g} \mathrm{~L}^{-1}$ as the adsorbent loading and $2.0 \mathrm{mg} \mathrm{L}^{-1}$ as the concentration of $\mathrm{As}$ (III) or As(V) solution. The solutions were shaken for $120 \mathrm{~min}$ (arsenite solution) and $60 \mathrm{~min}$ (arsenate solution) at a temperature of $303 \mathrm{~K}$ (contact time explained in the next section). Arsenite remained as a neutral species $\left(\mathrm{H}_{3} \mathrm{AsO}_{3}\right)$ in the $\mathrm{pH}$ range of 2-7. The $\mathrm{p} K_{\mathrm{a}}$ values of $\mathrm{H}_{3} \mathrm{AsO}_{3}\left(\mathrm{p} K_{1}=9.2\right.$, $\mathrm{p} K_{2}=12.3$ and $\mathrm{p} K_{3}=13.4$ ) and zeta potential measurements with respect to $\mathrm{pH}$ suggested that under acidic conditions, the surface $-\mathrm{OH}$ and $-\mathrm{NH}$ groups are protonated [29]. Thus there is no electrostatic attraction between the positively charged surface and neutral As(III) species. At pH of around 7.5, $\mathrm{H}_{3} \mathrm{AsO}_{3}$ starts dissociating to arsenite ions $\left(\mathrm{H}_{2} \mathrm{AsO}_{3}{ }^{1-}\right.$ and $\left.\mathrm{HAsO}_{3}{ }^{2-}\right)$. At around neutral $\mathrm{pH}$, strong interactions are observed between partially neutral and partially negatively charged arsenite species and the positively charged adsorbent surface. Thus, PLP-As(III) interactions resulted in maximum adsorption of $63.3 \%$ at $\mathrm{pH} 7.5$ (Fig. 4). As pH was further increased, the repulsion between the anionic species and negatively charged surface resulted in a decrease in adsorption of the anions.

Arsenate exists as a monovalent ion, $\mathrm{H}_{2} \mathrm{AsO}_{4}{ }^{1-}$, in the $\mathrm{pH}$ range of 2-6.1. Arsenate $\left(\mathrm{H}_{2} \mathrm{AsO}_{4}{ }^{1-}\right) \mathrm{pK}$ a values are $\mathrm{p} K_{1}=2.2, \mathrm{p} K_{2}=7.1$ and $\mathrm{p} K_{3}=11.5$, which are lower than those of the arsenite divalent ion $\left(\mathrm{as} \mathrm{HAsO}_{4}{ }^{2-}\right.$ in the $\mathrm{pH}$ range of 6.1-11.5) [29,35]. At $\mathrm{pH}>\mathrm{pzc}(2.3)$ and $\mathrm{pH}>\mathrm{pK} K_{1}$, the surface of the PLP particles acquires negative charge. Under acidic conditions, however, the surface is highly protonated. There is a strong electrostatic attraction between positively charged surface sites $(-\mathrm{OH}$ and $-\mathrm{NH}$ groups) and negatively charged arsenic anions [20], showing maximum $\mathrm{As}(\mathrm{V})$ removal of $67.6 \%$ at pH 3.0 (Fig. 4). As the pH of the solution increases, the substrate ends may acquire negative charge by adsorbing $\mathrm{OH}^{-}$ions or by ionization of weak acidic functional groups or both, so there involve strong repulsive forces between the negative surface and $\mathrm{HAsO}_{4}{ }^{2-}$.

A similar observation was reported earlier by Ranjan et al., where adsorption reached a maximum at $\mathrm{pH} 7.0$ for $\mathrm{As}(\mathrm{III})$ and $\mathrm{pH} 4.0$ for $\mathrm{As}(\mathrm{V})$ when rice polish was used as the adsorbent [24]. Another study by Lin et al. reported maximum adsorption (>50\%) for $\mathrm{As}(\mathrm{III})$ at $\mathrm{pH} 7.5$ and (>60\%) for As(V) at pH 3.0 [29]. 
Fig. 2 SEM micrographs (at magnification $\times 20,000$ ) of raw $\operatorname{PLP}(\mathbf{a})$, As(III)-loaded PLP (c), and $\mathrm{As}(\mathrm{V})$-loaded PLP (e); EDX analysis of raw PLP (b), As(III)loaded PLP (d), and As(V)loaded PLP (f)
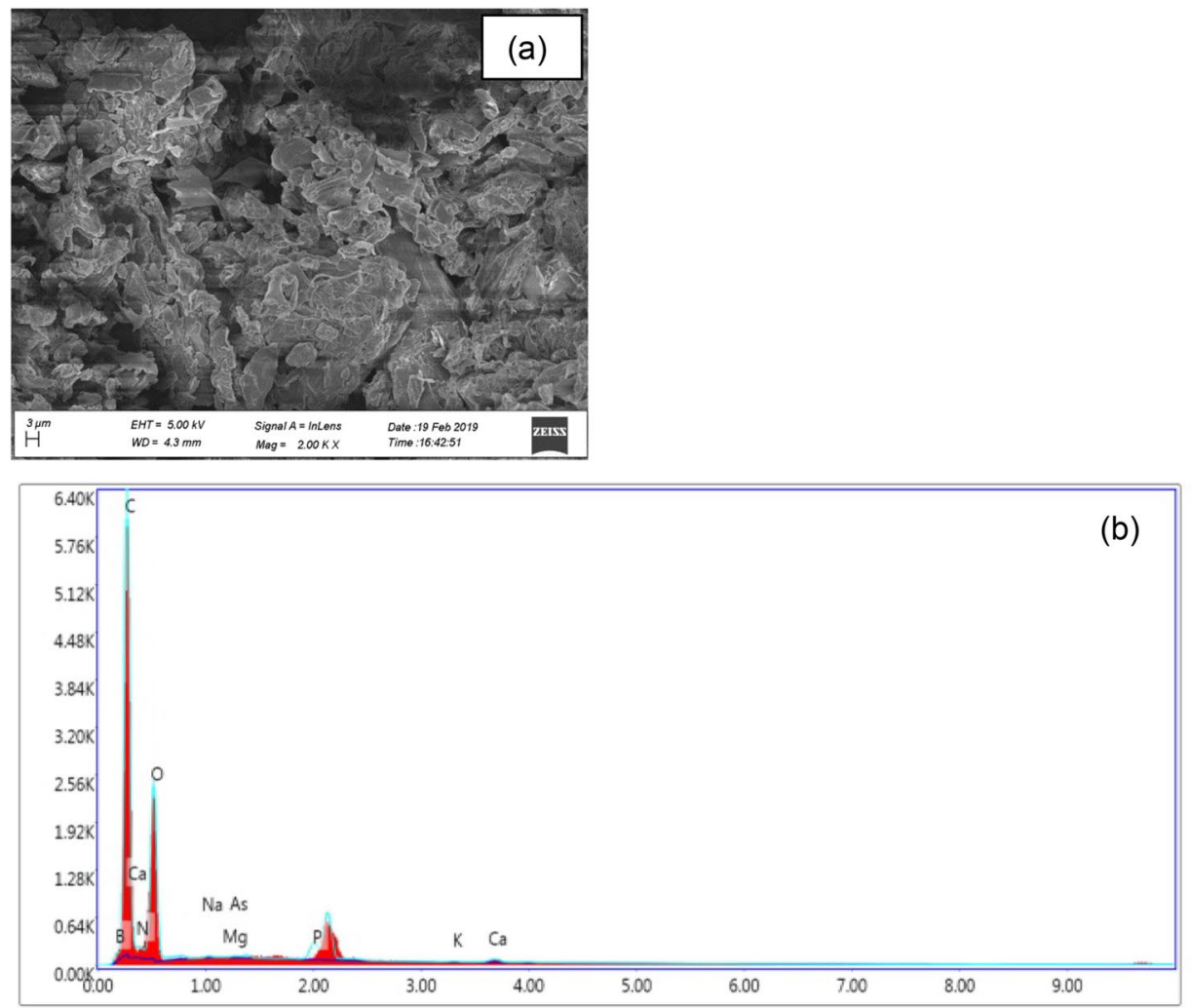

Lsec: $20.0 \quad 0$ Cnts $0.000 \mathrm{keV} \quad$ Det: Element-C2B
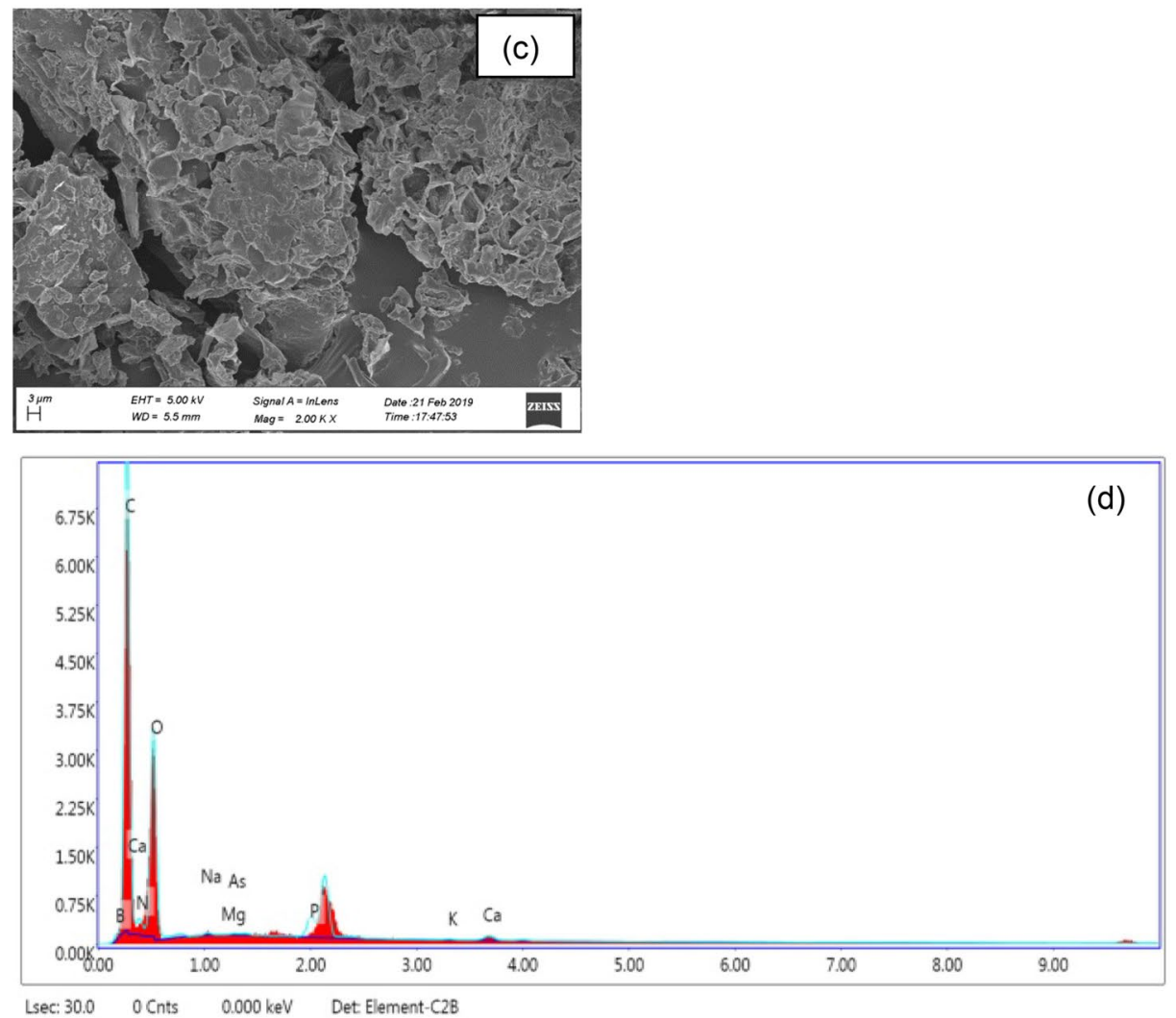
Fig. 2 (continued)
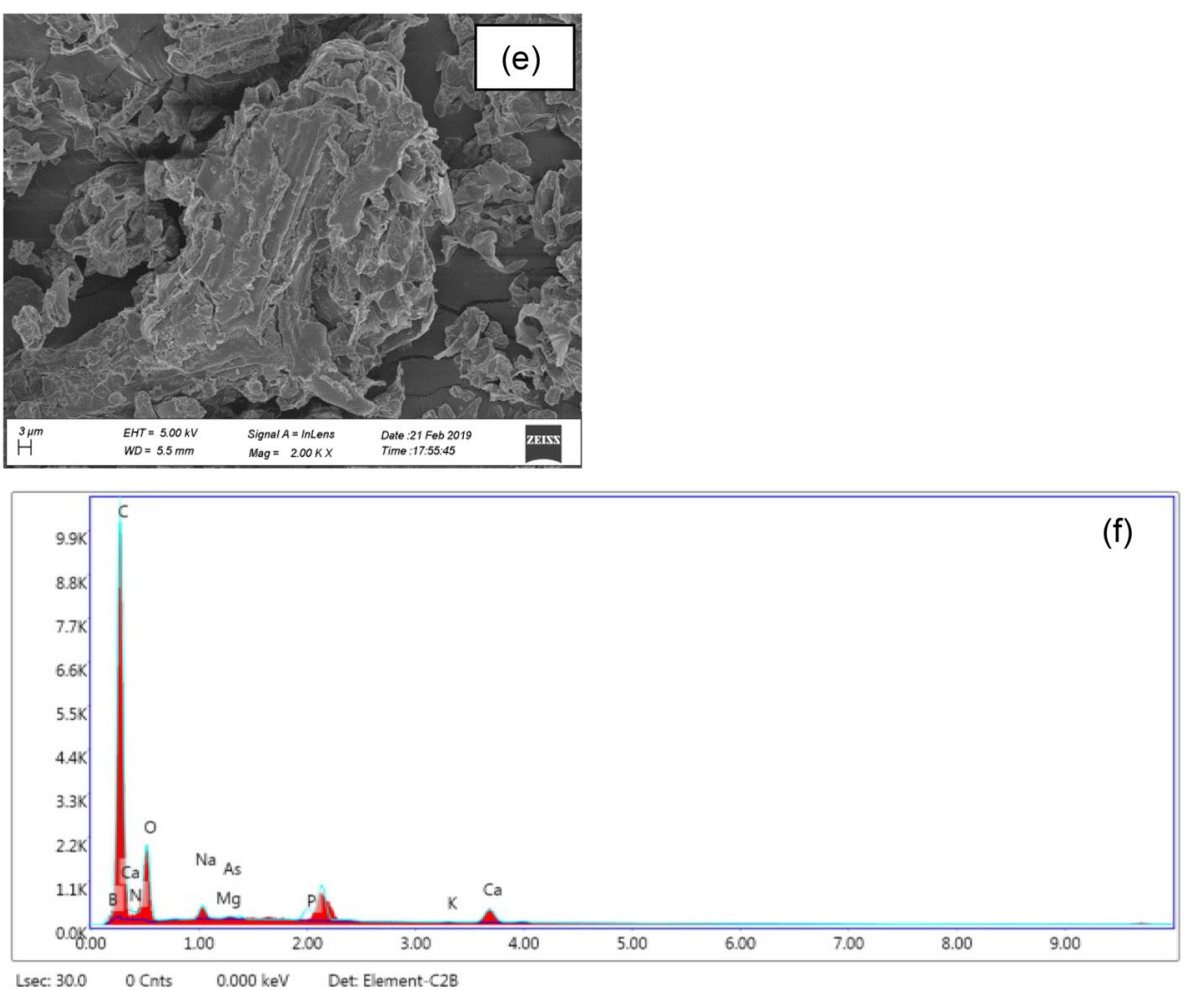

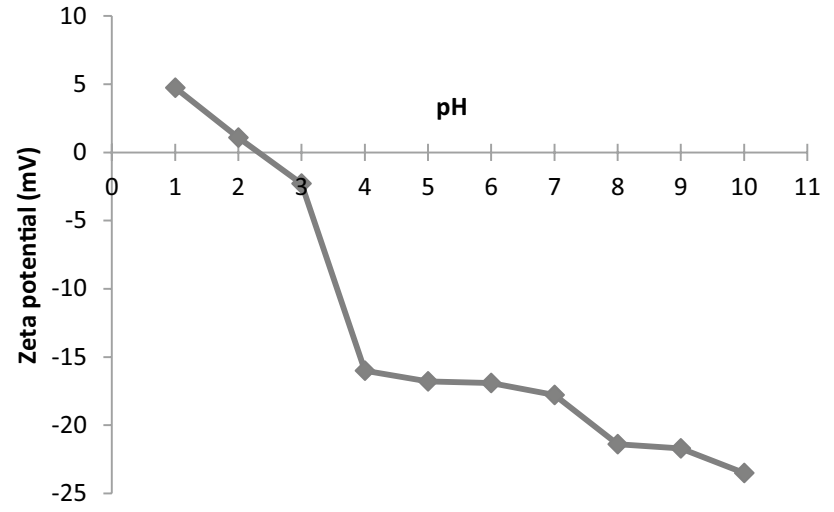

Fig. 3 Zeta potential of PLP suspensions against $\mathrm{pH}$ at $303 \mathrm{~K}$

\subsubsection{Effects of contact time and adsorption kinetics}

The effects of contact time and adsorption kinetics were studied with PLP loading of $1.0 \mathrm{~g} \mathrm{~L}^{-1}$ and As(III) or As(V) concentration of $2.0 \mathrm{mg} \mathrm{L}^{-1}$ at $303 \mathrm{~K}$, without adjusting the $\mathrm{pH}$. The Erlenmeyer flasks were removed from the thermostatic water bath shaker at adsorption time intervals of 5 to $360 \mathrm{~min}$ to measure the extent of adsorption. Adsorption of $A s(I I)$ and $A s(V)$ on PLP was found to attain equilibrium within 120 and $60 \mathrm{~min}$, respectively (Fig. 5). The process appeared to be a two-step process, firstly consisting of a fast adsorption step at the

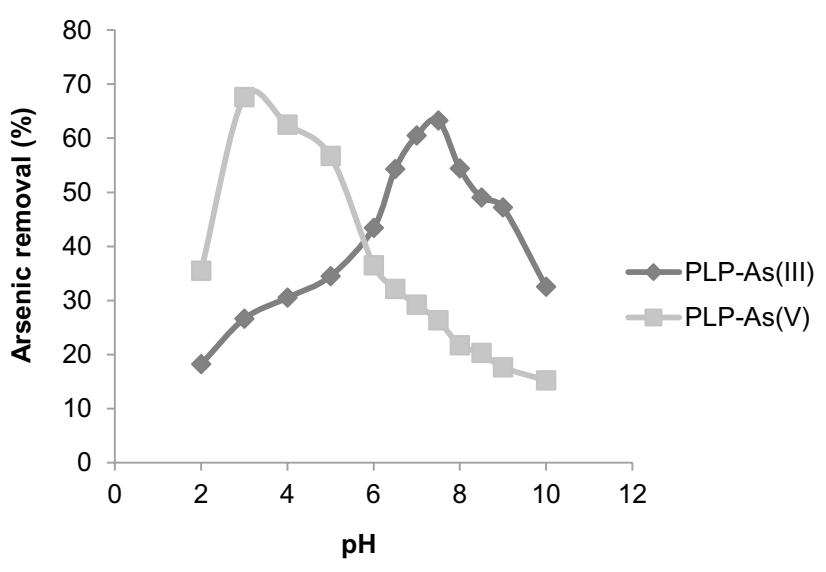

Fig. 4 Effects of pH on adsorption of As(III) and As(V) by PLP. Concentration of $\mathrm{As}^{3+}$ or $\mathrm{As}^{5+}$ solution $2.0 \mathrm{mg} \mathrm{L}^{-1}$; adsorbent amount $1 \mathrm{~g} \mathrm{~L}^{-1}$ and temperature $303 \mathrm{~K}$

beginning, indicating rapid filling of the sites from the large number of available bare binding sites, followed by a slower step, with no significant increase in arsenic uptake. At equilibrium, some of the binding sites were saturated by adsorption of arsenic anions. The remaining unsaturated sites could no longer be approached by arsenic anions in solution due to (i) repulsive forces generated among the adsorbed arsenic anions and (ii) repulsion of arsenic anions in the solid phase (PLP) and those in the solution [55].

\section{SN Applied Sciences}




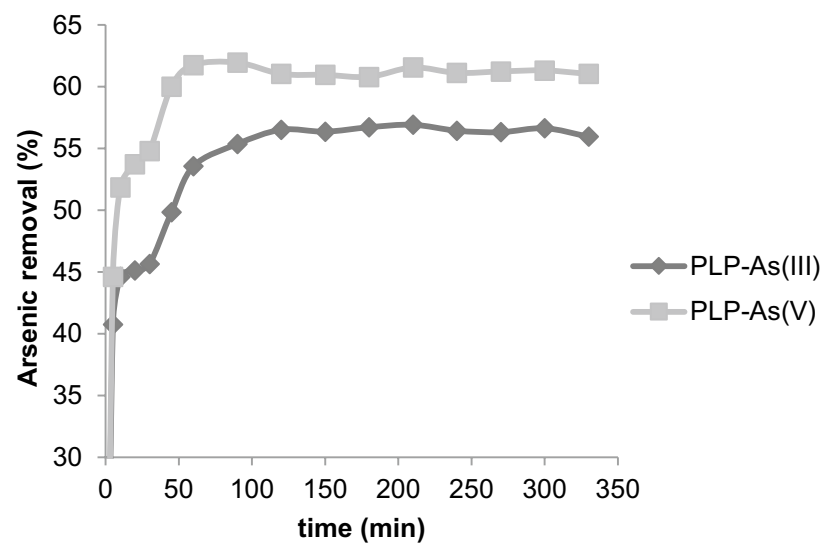

Fig. 5 Effects of time on adsorption of As(III) and As(V) by PLP. Concentration of $\mathrm{As}^{3+}$ or $\mathrm{As}^{5+}$ solution $5.0 \mathrm{mg} \mathrm{L}^{-1}$; adsorbent amount $1 \mathrm{~g} \mathrm{~L}^{-1}$ and temperature $303 \mathrm{~K}$

The pseudo-first-order kinetics plots as per Eq. (3) are shown in Fig. 6a. The pseudo-first-order rate constant $k_{1}$ and the equilibrium solid-phase concentration $q_{\mathrm{e}^{\prime}}$ obtained respectively from the slopes and the intercepts of the plots of $\log \left(q_{\mathrm{e}}-q_{\mathrm{t}}\right)$ vs. $t$, are listed in Table 3. The good linearity of the plots is indicated by the correlation coefficient $\left(R^{2}\right)$ values of 0.95 for $\mathrm{As}^{3+}$ and 0.90 for $\mathrm{As}^{5+}$, but the differences between the values of $q_{\mathrm{e}}$ obtained from the plots and the experimentally measured $q_{\mathrm{e}}$ (exp) are very large, and the pseudo-first-order model has to be discarded for arsenic adsorption on PLP. The large deviation $\left(63.96 \%\right.$ for $\mathrm{As}^{3+}$ and $65.96 \%$ for $\mathrm{As}^{5+}$ ) between $q_{\mathrm{e}}$ (exp) and $q_{\mathrm{e}}$ (plot) could have been because $q_{\mathrm{e}}$ (plot) was obtained from the intercept at $t=0$ when As uptake was much lower than that at equilibrium [56].

Pseudo-second-order kinetics plots for $\mathrm{As}$ (III) and $\mathrm{As}(\mathrm{V})$ adsorption on PLP are presented in Fig. 6b, and the corresponding $q_{\mathrm{e}^{\prime}} k_{2}, R^{2}$ values are reported in Table 3. The plots of $t / q_{t}$ versus $t$ are highly linear $\left(R^{2}=0.99\right)$ and show good agreement between $q_{\mathrm{e}}$ (plot) and $q_{\mathrm{e}}$ (exp), with only small deviations. The values of the pseudo-second-order rate coefficient, $k_{2}$, computed from the plots were $6.79 \times 10^{-2}$ and $10.18 \times 10^{-2} \mathrm{~g} \mathrm{mg}^{-1} \mathrm{~min}^{-1}$ for As(III) and $\mathrm{As}(\mathrm{V})$, respectively. These values compare well with the second-order kinetics coefficient of $6.55 \times 10^{-2} \mathrm{~g} \mathrm{mg}^{-1} \mathrm{~min}^{-1}$ measured for As(III) adsorption on acidified laterite by Glocheux et al. for particles of size $<75 \mu \mathrm{m}$ at $303 \mathrm{~K}$ [57]. However, the few works on the removal of As(III) by cellulose-based adsorbents have reported lower $k_{2}$ values of $0.061 \times 10^{-2} \mathrm{~g} \mathrm{mg}^{-1} \mathrm{~min}^{-1}$ (rice polish) [24] and $0.069 \times 10^{-2} \mathrm{~g} \mathrm{mg}^{-1} \mathrm{~min}^{-1}$ (Acacia nilotica leaf powder) [58] in comparison with those found in the present work. Much smaller $k_{2}$ values of $0.011 \times 10^{-2} \mathrm{~g} \mathrm{mg}^{-1} \mathrm{~min}^{-1}$ and $0.921 \times 10^{-2} \mathrm{~g} \mathrm{mg}^{-1} \mathrm{~min}^{-1}$ were obtained for As(V) (a)

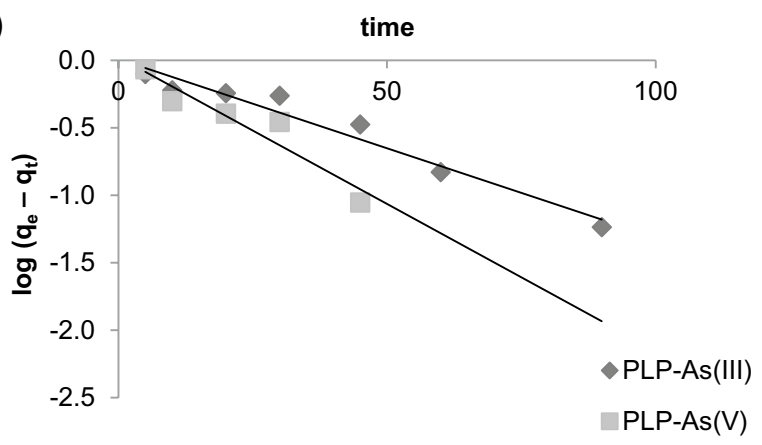

(b)

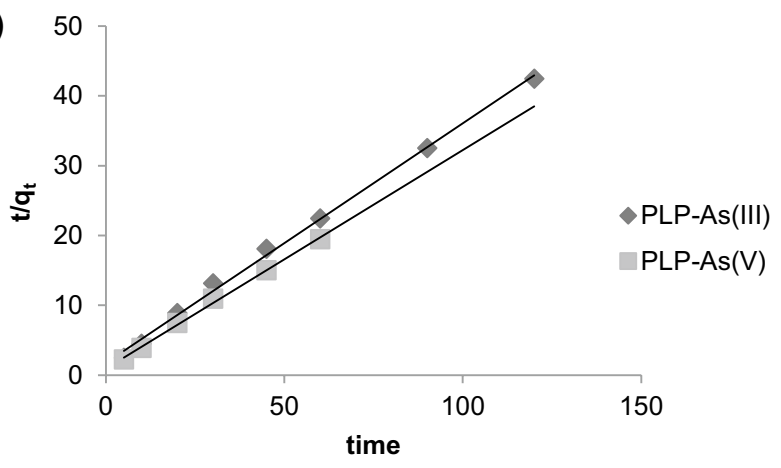

(c)

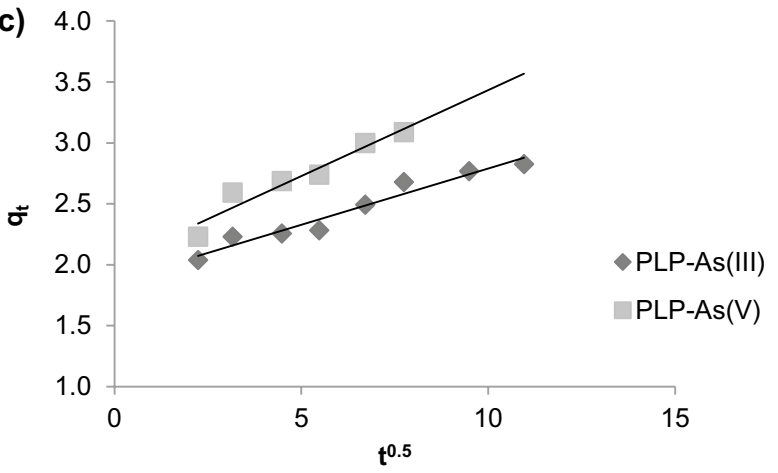

Fig. 6 Fitting of experimental data based on pseudo-first-order (a), pseudo-second-order (b) and intra-particle diffusion kinetic (c) models. Concentration of $\mathrm{As}^{3+}$ or $\mathrm{As}^{5+}$ solution $5.0 \mathrm{mg} \mathrm{L}^{-1}$; adsorbent amount $1 \mathrm{~g} \mathrm{~L}^{-1}$ and temperature $303 \mathrm{~K}$

adsorption by multi-amino-functionalized cellulose [39] and by Arthrobacter sp. biomass [38], respectively.

The values of $k_{i}$ were determined from the slopes of the respective plots, as indicated in Fig. $6 \mathrm{c}$ (Table 3). Although the plots were linear, the straight line did not pass through the origin. This non-zero intercept of the intra-particle diffusion model reflects the boundary layer thickness, which is attributed to film diffusion; the larger the intercept, the greater the contribution of the boundary layer (film) diffusion in the rate-controlling step. Thus, it is possible that arsenite and arsenate ions diffuse through a large boundary layer and prefer surface sorption $[59,60]$. 
Table 3 Kinetic parameters obtained from adsorption of $\mathrm{As}(\mathrm{III})$ and $\mathrm{As}(\mathrm{V})$ onto PLP

\begin{tabular}{llcc}
\hline Kinetics & Parameters & PLP-As(III) & PLP-As(V) \\
\hline Pseudo-first order & $k_{1} \times 10^{2} \mathrm{~min}^{-1}$ & 3.04 & 5.00 \\
& $R^{2}$ & 0.95 & 0.90 \\
& $q_{\mathrm{e}}$ (exp) $\mathrm{mg} \mathrm{g}^{-1}$ & 2.83 & 3.09 \\
& $q_{\mathrm{e}}$ (plot) $\mathrm{mg} \mathrm{g}^{-1}$ & 1.02 & 1.05 \\
& $\%$ deviation & 63.96 & 65.96 \\
Pseudo-second & $k_{2} \times 10^{2} \mathrm{~g} \mathrm{mg}^{-1} \mathrm{~min}^{-1}$ & 6.79 & 10.18 \\
order & $R^{2}$ & 0.99 & 0.99 \\
& $q_{\mathrm{e}}$ (exp) $\mathrm{mg} \mathrm{g}^{-1}$ & 2.83 & 3.09 \\
& $q_{\mathrm{e}}$ (plot) $\mathrm{mg} \mathrm{g}^{-1}$ & 2.91 & 3.20 \\
Intra-particle dif- & $\%$ deviation & -2.82 & -3.56 \\
fusion & $\mathrm{k}_{\mathrm{i}} \times 10^{2} \mathrm{mg} \mathrm{g}^{-1} \mathrm{~min}^{-0.5}$ & 9.26 & 14.14 \\
& $R^{2}$ & 0.95 & 0.93 \\
& Intercept $\left(\mathrm{mg} \mathrm{g}^{-1}\right)$ & 1.86 & 2.02 \\
\hline
\end{tabular}

\subsubsection{Effects of adsorbent loading and As(III), As(V) concentration}

Adsorption of $\mathrm{As}(\mathrm{III})$ and $\mathrm{As}(\mathrm{V})$ was studied by varying the PLP amount from 1.0 to $5.0 \mathrm{~g} \mathrm{~L}^{-1}$, with a fixed concentration of arsenite or arsenate solution of $2.0 \mathrm{mg} \mathrm{L}^{-1}$, and without adjusting the $\mathrm{pH}$. The interactions were carried out until equilibrium was attained at $303 \mathrm{~K}$. Adsorption of arsenic anions was enhanced with the increase in the biosorbent amount due to an increase in the number of binding sites available on the surface of the adsorbent for the uptake of arsenic anions [61]. Maximum removal was 79.9\% for $\mathrm{As}^{3+}$ and $80.5 \%$ for $\mathrm{As}^{5+}$, and these values were achieved with $4.0 \mathrm{~g} \mathrm{~L}^{-1}$ PLP (Fig. 7a). No significant increase in adsorption was observed when the PLP amount was further increased. This may be because equilibrium conditions were reached between the liquid-phase and the solid-phase arsenite or arsenate ions. On the other hand, the adsorption capacity $\left(q_{\mathrm{e}}\right)$ of the adsorbent was reduced from 1.11 to $0.316 \mathrm{mg} \mathrm{g}^{-1}\left(\mathrm{As}^{3+}\right)$ and from 1.18 to $0.318 \mathrm{mg} \mathrm{g}^{-1}\left(\mathrm{As}^{5+}\right)$. This is because, although the adsorbent amount increases, the number of arsenic anions adsorbed by a unit mass of adsorbent decreases.

In a separate experiment, As(III) at an initial concentration varying from 0.5 to $5.0 \mathrm{mg} \mathrm{L}^{-1}$ was mixed with a constant PLP amount (1.0, 2.0, and $3.0 \mathrm{~g} \mathrm{~L}^{-1}$ constant for each set of the experiments) at a temperature of $303 \mathrm{~K}$ and $\mathrm{pH}$ as prepared. The adsorption of As(III) decreased from 72.00 to $41.72 \%$ (PLP amount, $1.0 \mathrm{~g} \mathrm{~L}^{-1}$ ), 78.8 to 45.72\% (PLP amount, $2.0 \mathrm{~g} \mathrm{~L}^{-1}$ ), and 86.4 to $58.96 \%$ (PLP amount, $3.0 \mathrm{~g} \mathrm{~L}^{-1}$ ) (Fig. 7b). Free adsorption sites were sufficiently available at low arsenite concentrations. At a relatively higher concentration of $\mathrm{As}$ (III), there are too many arsenite ions competing for each binding site on the
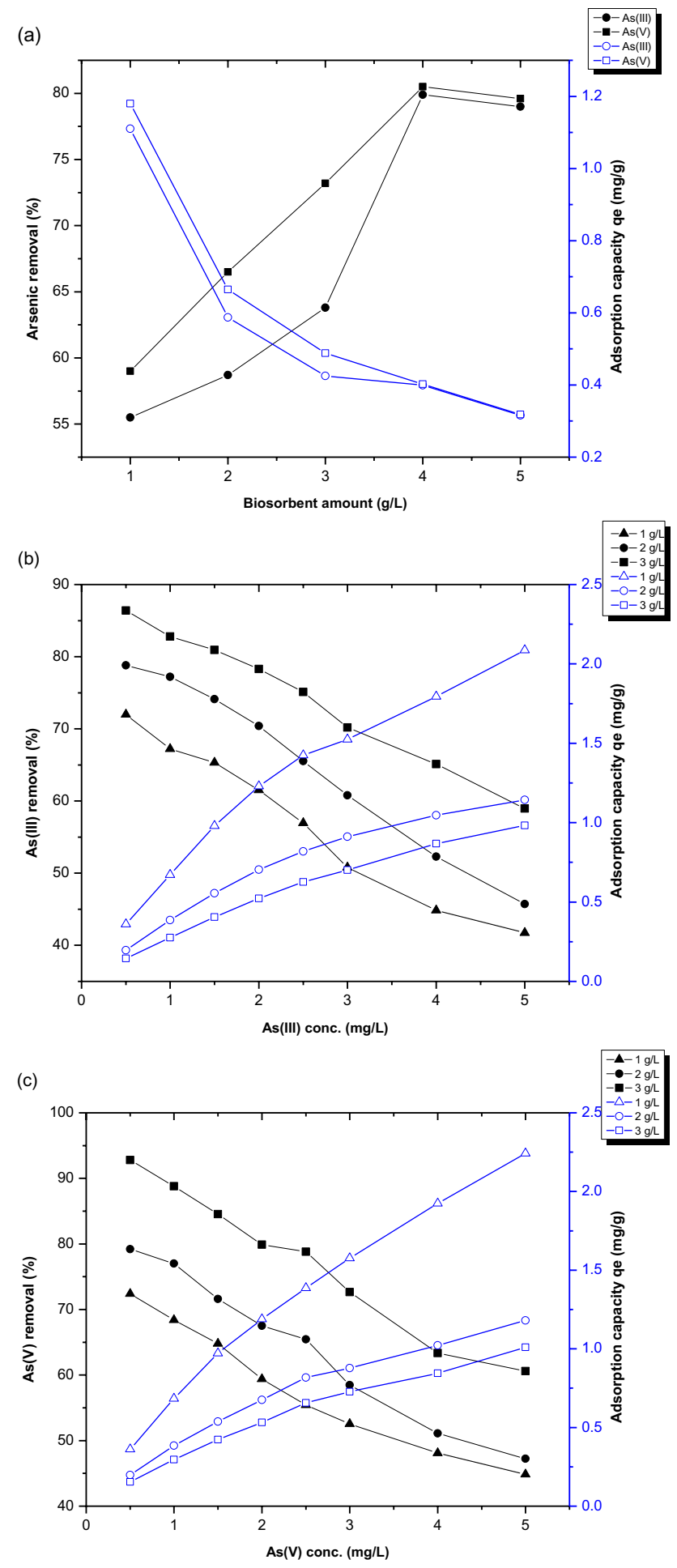

Fig. 7 Adsorption of arsenic when: adsorbent amount is varied from 1 to $5 \mathrm{~g} \mathrm{~L}^{-1}$ at constant $\mathrm{As}(\mathrm{III})$ or $\mathrm{As}(\mathrm{V})$ concentration of $2 \mathrm{mg} \mathrm{L}^{-1}(\mathrm{a})$; $\mathrm{As}(\mathrm{III})$ concentration is in the range of $0.5-5.0 \mathrm{mg} \mathrm{L}^{-1}$ at adsorbent amounts of 1,2 and $3 \mathrm{~g} \mathrm{~L}^{-1}(\mathbf{b})$; and $\mathrm{As}(\mathrm{V})$ concentration is in the range of $0.5-5.0 \mathrm{mg} \mathrm{L}^{-1}$ at adsorbent amounts of 1,2 and $3 \mathrm{~g} \mathrm{~L}^{-1}$ (c) 
biosorbent surface, and this results in decreased adsorption. The active sites available for adsorption are gradually saturated with As(III) ions per unit mass of PLP. Thus, the $q_{\mathrm{e}}$ value increases almost linearly for each set of As(III) concentration at a constant amount of PLP. For each set of As(III) concentration, the parameter $q_{\mathrm{e}}$ decreases with an increase in PLP amount.

Another set of experiments with varying $A s(V)$ concentration (0.5-5.0 $\mathrm{mg} \mathrm{L}^{-1}$ ) and PLP amount constant (1.0, 2.0, and $3.0 \mathrm{~g} \mathrm{~L}^{-1}$ for each set) at a temperature of $303 \mathrm{~K}$ gave similar results (Fig. 7c). The removal of As(V) decreased from 72.4 to $44.84 \%$ (PLP amount, $1.0 \mathrm{~g} \mathrm{~L}^{-1}$ ), 79.2 to $47.24 \%$ (PLP amount, $2.0 \mathrm{~g} \mathrm{~L}^{-1}$ ), and 92.8 to $60.6 \%$ (PLP amount, $\left.1.0 \mathrm{~g} \mathrm{~L}^{-1}\right)$, while $q_{\mathrm{e}}$ plots were in reverse order.

\subsubsection{Effects of co-existing anions}

The effects of phosphate on $\mathrm{As}(\mathrm{III})$ and $\mathrm{As}(\mathrm{V})$ removal were studied in the presence of three $\mathrm{PO}_{4}{ }^{3-}$ concentrations $\left(0.5,2.5\right.$, and $\left.5.0 \mathrm{mg} \mathrm{L}^{-1}\right)$ at a constant concentration of arsenic anions with adsorbent amount of $1 \mathrm{~g} \mathrm{~L}^{-1}$ at $303 \mathrm{~K}$. The percentage removal of $\mathrm{As}(\mathrm{III})$ and $\mathrm{As}(\mathrm{V})$ was 67.2 and $68.4 \%$, respectively, at an initial As concentration of $1.0 \mathrm{mg} \mathrm{L}^{-1}$ in the absence of phosphate ions. When phosphate ions were present, the $\mathrm{As}(\mathrm{III})$ and $\mathrm{As}(\mathrm{V})$ removal capacity decreased sharply, from 67.2 to $36.6 \%$ and from 68.4 to $24.6 \%$, respectively (Fig. 8a). The $\mathrm{pH}$ of the solutions was found to be in the range of 5.5-7.5. Under neutral conditions, the competition between $\mathrm{HPO}_{4}{ }^{2-}$ and $\mathrm{H}_{3} \mathrm{AsO}_{3}$ or $\mathrm{HAsO}_{4}{ }^{2-}$ for the adsorption sites of the adsorbent may result in reduced sorption of the arsenic species [24, 29]. The removal rate of As(III) and As $(\mathrm{V})$ decreased to approximately $45 \%$ and $64 \%$, respectively, in the presence of phosphate, as compared with that of the control (absence of phosphate). The greater influence of phosphate on the adsorption of arsenate may be attributed to the fact that phosphoric acid and arsenic acid are triprotic acids with similar structure and properties. A further increase in $\mathrm{PO}_{4}{ }^{3-}$ concentration showed no significant decrease in $\mathrm{As}(\mathrm{III})$ or $\mathrm{As}(\mathrm{V})$ adsorption on PLP. It is likely that the PLP surface became saturated with the increasing number of phosphate ions, blocking many of the binding sites, and the competition for the adsorption sites between $\mathrm{As}(\mathrm{III})$ and $\mathrm{As}(\mathrm{V})$ ions on the one hand and phosphate ions on the other reaching some kind of a dynamic equilibrium. Similar results were obtained by Lin et al. [4] and Ansone et al. [29] for adsorption of arsenic on plant-based biomaterials.

Similarly, the effects of the presence of borate ions on $\mathrm{As}(\mathrm{III})$ and $\mathrm{As}(\mathrm{V})$ removal was studied by varying the $\mathrm{BO}_{3}{ }^{3-}$ concentration from 0.5 to $5.0 \mathrm{mg} \mathrm{L}^{-1}$. It was found that As(III) adsorption decreased dramatically from 67.2 to $30.2 \%$ in the presence of borate ions. A further increase in borate concentration decreased arsenite sorption only gradually (Fig. 8b). The effects of borate ions on As(III) adsorption on PLP can be explained in a way identical to the effects of the presence of phosphate ions on the adsorption of $\mathrm{As}(\mathrm{III})$ and $\mathrm{As}(\mathrm{V})$. This might be because under neutral conditions, arsenite and borate exist as $\mathrm{H}_{3} \mathrm{AsO}_{3}$ and $\mathrm{H}_{3} \mathrm{BO}_{3}$, respectively, both having a trigonal planar structure. The two anionic species share common sorption sites, and there is likely to be stiff competition between arsenite and borate for the available adsorption sites on the surface of PLP particles, resulting in the inhibition of $\mathrm{As}$ (III) adsorption in the presence of borate ions. Similar trends were reported earlier by Su and Puls [62]. The absence of such structural similarity between arsenate and borate species could be the reason that the PLP particles demonstrated very little or no change with respect to $\mathrm{As}(\mathrm{V})$ adsorption even in the presence of $\mathrm{BO}_{3}{ }^{3-}$ ions (Fig. 8b). These results further confirm that the process of removal of $\mathrm{As}(\mathrm{III})$ and $\mathrm{As}(\mathrm{V})$ anions by PLP occurs through surface adsorption, which is not affected by the presence of other anionic species if they do not have structural similarity with arsenite or arsenate ions.
Fig. 8 Effect of co-existing anions phosphate $\left(\mathrm{PO}_{4}{ }^{3-}\right)(\mathbf{a})$ and borate $\left(\mathrm{BO}_{3}{ }^{3-}\right)(\mathbf{b})$. Concentration of $\mathrm{As}(\mathrm{III})$ and $\mathrm{As}(\mathrm{V})$ $1 \mathrm{mg} \mathrm{L}^{-1}$; adsorbent amount of $1 \mathrm{~g} \mathrm{~L}^{-1}$ at $303 \mathrm{~K}$ (a)

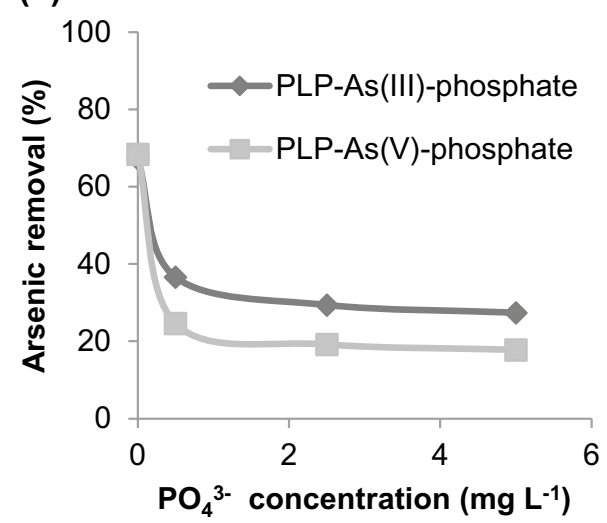

(b)

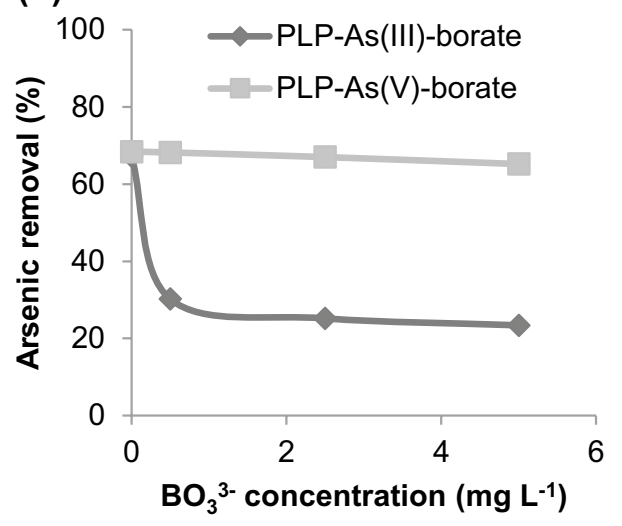




\subsection{Adsorption isotherms}

The adsorption isotherm experiments were conducted by preparing a set of solutions (concentration range, $0.5-5.0 \mathrm{mg} \mathrm{L}^{-1}$ ) in which the amount of adsorbent was varied at 1,2 , and $3 \mathrm{~g} \mathrm{~L}^{-1}$ at $303 \mathrm{~K}$. The adsorption capacity and other parameters obtained from the adsorption isotherm models by varying the amount of PLP are given in Table 4. The experimental data are in good agreement with the Freundlich isotherm, as the plots show good linearity (correlation coefficient, $R^{2}=0.96 \mathrm{As}(\mathrm{III})$ and $0.98 \mathrm{As}(\mathrm{V})$ ) (Fig. 9a,b). The uptake of arsenic species on PLP is found to be favorable, as $1 / \mathrm{n}=0.55$ and 0.52 is less than unity for $\mathrm{As}(\mathrm{III})$ and $\mathrm{As}(\mathrm{V})$, respectively. The Freundlich adsorption capacity is found to be the same $\left(1.28 \mathrm{mg}^{1-1 / n} \mathrm{~L}^{1 / n} \mathrm{~g}^{-1}\right)$ for both $\mathrm{As}(\mathrm{III})$ and $\mathrm{As}(\mathrm{V})$ adsorption.

Application of the Langmuir model showed that the adsorption of $\mathrm{As}(\mathrm{III})$ and $\mathrm{As}(\mathrm{V})$ by PLP was the best-fit isotherm model, with high correlation coefficient values of 0.99 and 0.98 for $\mathrm{As}$ (III) and $\mathrm{As}(\mathrm{V})$, respectively (Fig. 9c, d). The Langmuir separation factor $\left(R_{L}\right)$ was found to be 0.27 $\left(\mathrm{As}^{3+}\right)$ and $0.28\left(\mathrm{As}^{5+}\right)$, again indicating that the uptake of arsenic is favored on the PLP surface $\left(0<R_{L}<1\right)$. Langmuir monolayer capacity of $1.76 \mathrm{mg} \mathrm{g}^{-1}\left(\mathrm{As}^{3+}\right)$ and $1.87 \mathrm{mg} \mathrm{g}^{-1}$ $\left(\mathrm{As}^{5+}\right)$ was obtained from the linear Langmuir isotherm plots. The results of the Freundlich and Langmuir models together suggest that arsenic anions were adsorbed on the heterogeneous surface of PLP in a monolayer by very strong adsorbate-adsorbent interactions [63]. A comparison of the Langmuir monolayer adsorption capacity of PLP with that of a few other biomaterials (Table 5) shows that PLP has a sufficiently large capacity to take up arsenic in both trivalent and pentavalent form from aqueous solution $[22-24,26,29,31-33,40,41,54,63,64]$.

These observations are further supported by linear Temkin plots (Fig. 9e, f) revealing strong As(III)-PLP and
As(V)-PLP interactions with negligible adsorbate-adsorbate interactions during the process. The Temkin coefficient, $k_{\mathrm{T}}$, is large, with a value of 16.28 and $22.60 \mathrm{~L} \mathrm{mg}^{-1}$ for arsenite and arsenate, respectively, showing that chemical interactions had precedence in the whole process of adsorption.

\subsection{Thermodynamics of the adsorption process}

To study the thermodynamics of adsorption, $1 \mathrm{~g} \mathrm{~L}^{-1} \mathrm{PLP}$ was added to a set of solutions of As(III) or As(V) (concentration range, $0.5-5.0 \mathrm{mg} \mathrm{L}^{-1}$ ). Different sets of such solutions were shaken at temperatures of 303,313 and $323 \mathrm{~K}$. The average values of the thermodynamic parameters were determined mathematically from Eqs. (10) and (11), which are summarized in Table 6. The adsorption process is exothermic, which is supported by the negative values of enthalpy of reaction. This may be attributed to the weakening of adsorptive forces between arsenic anions and the adsorbent surface as the temperature rises, resulting in increased anion mobility. The adsorption capacity values decrease with an increase of temperature from 303 to $323 \mathrm{~K}$. The average values of standard enthalpy of reaction, $\Delta H_{\text {av }}^{\circ}$, were obtained in the range of $5.71-20.46 \mathrm{~kJ} \mathrm{~mol}^{-1}$ and $3.44-10.19 \mathrm{~kJ} \mathrm{~mol}^{-1}$ for adsorption of $\mathrm{As}(\mathrm{III})$ and $\mathrm{As}(\mathrm{V})$, respectively. This corresponds to physical adsorption [25]. Therefore, adsorption of As(III) and As(V) occurs through physisorption, where arsenic species are held by weak van der Waals forces $[58,65]$.

The negative values of standard entropy change of reaction, $\Delta S^{\circ}{ }_{a v}$ indicate that arsenic adsorption on PLP is accompanied by a decrease in entropy (for both $\mathrm{As}^{3+}$ and $\mathrm{As}^{5+}$ adsorption), which may be due to immobilization or association of arsenic anions on the adsorbent surface. Baig et al. [30] and Yu et al. [39] reported similar trends in the values of $\Delta G^{\circ}, \Delta H^{\circ}$, and $\Delta S^{\circ}[39,58]$.
Table 4 Freundlich, Langmuir, and Temkin isotherm parameters for $\mathrm{As}(\mathrm{III})$ and $\mathrm{As}(\mathrm{V})$ adsorption on PLP

\begin{tabular}{|c|c|c|c|c|c|c|c|c|c|}
\hline \multirow[t]{3}{*}{ Isotherm } & \multirow[t]{3}{*}{ Parameters } & \multicolumn{4}{|c|}{ As(III) adsorption } & \multicolumn{4}{|c|}{$\mathrm{As}(\mathrm{V})$ adsorption } \\
\hline & & \multicolumn{3}{|c|}{ Adsorbent amount $\left(\mathrm{g} \mathrm{L}^{-1}\right)$} & \multirow[t]{2}{*}{ Mean } & \multicolumn{3}{|c|}{ Adsorbent amount $\left(\mathrm{g} \mathrm{L}^{-1}\right)$} & \multirow[t]{2}{*}{ Mean } \\
\hline & & 1 & 2 & 3 & & 1 & 2 & 3 & \\
\hline \multirow[t]{4}{*}{ Langmuir } & $R^{2}$ & 0.99 & 0.99 & 0.99 & 0.99 & 0.98 & 0.99 & 0.98 & 0.98 \\
\hline & $q_{m}\left(\mathrm{mg} \mathrm{g}^{-1}\right)$ & 2.65 & 1.39 & 1.24 & 1.76 & 3.05 & 1.44 & 1.12 & 1.87 \\
\hline & $b\left(\mathrm{~L} \mathrm{mg}^{-1}\right)$ & 1.06 & 1.65 & 1.67 & 1.46 & 0.85 & 1.44 & 2.77 & 1.69 \\
\hline & $R_{\mathrm{L}}$ & 0.34 & 0.22 & 0.25 & 0.27 & 0.38 & 0.28 & 0.18 & 0.28 \\
\hline \multirow[t]{3}{*}{ Freundlich } & $R^{2}$ & 0.97 & 0.94 & 0.98 & 0.96 & 0.99 & 0.97 & 0.98 & 0.98 \\
\hline & $K_{\mathrm{f}}\left(\mathrm{mg} \mathrm{g}^{-1}\right)$ & 1.34 & 1.25 & 1.24 & 1.28 & 1.29 & 1.28 & 1.27 & 1.28 \\
\hline & $N$ & 1.77 & 1.78 & 1.89 & 1.81 & 1.69 & 1.88 & 2.18 & 1.92 \\
\hline \multirow[t]{3}{*}{ Temkin } & $R^{2}$ & 0.98 & 0.99 & 0.98 & 0.98 & 0.96 & 0.98 & 0.96 & 0.96 \\
\hline & $b_{\top}\left(\mathrm{kJ} \mathrm{mol}^{-1}\right)$ & 4.48 & 8.42 & 9.96 & 7.62 & 4.10 & 8.38 & 12.00 & 8.16 \\
\hline & $k_{\mathrm{T}}\left(\mathrm{L} \mathrm{mg}^{-1}\right)$ & 11.58 & 17.28 & 19.99 & 16.28 & 10.22 & 16.15 & 41.43 & 22.60 \\
\hline
\end{tabular}


Fig. 9 Isotherm models for As(III) adsorption: Freundlich (a), Langmuir model (c) and Temkin model (e); for As(V) adsorption: Freundlich (b), Langmuir model (d) and Temkin model (f). Concentration of $\mathrm{As}^{3+}$ or $\mathrm{As}^{5+}$ solution $0.5-5.0 \mathrm{mg} \mathrm{L}^{-1}$; adsorbent amounts of 1, 2 and $3 \mathrm{~g} \mathrm{~L}^{-1}$ and temperature $303 \mathrm{~K}$
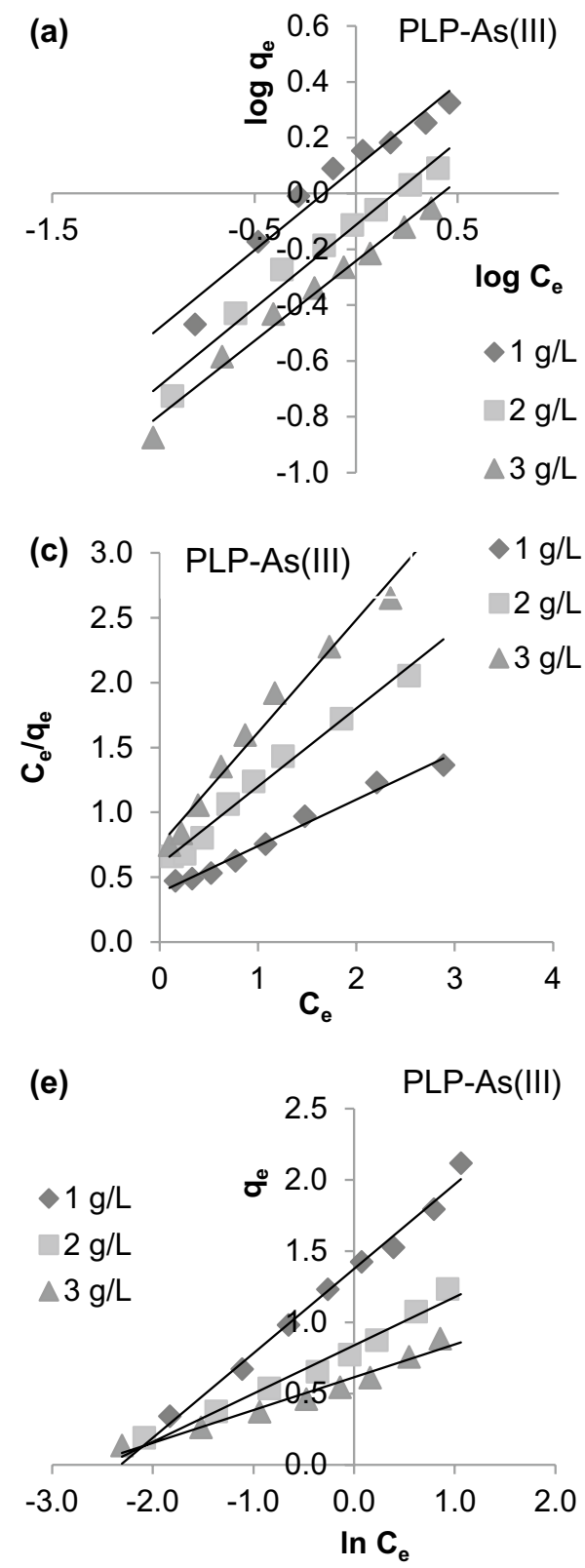
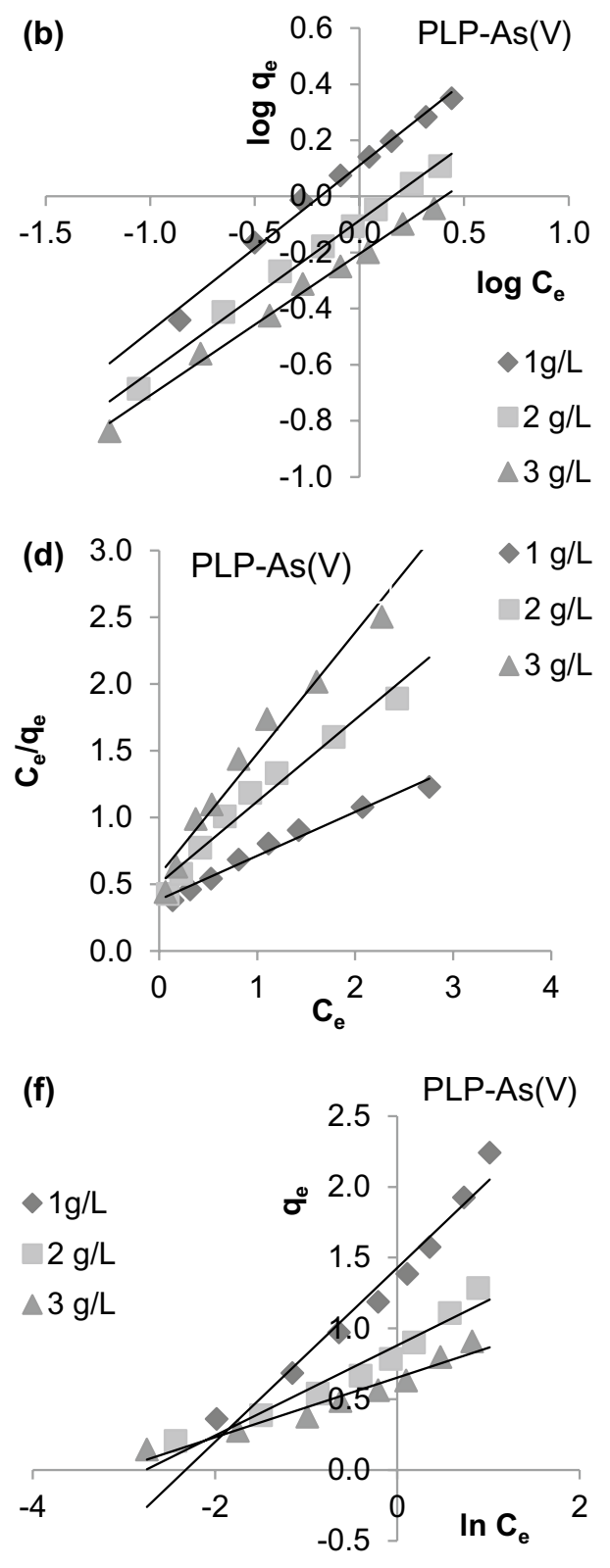

Negative values of standard free-energy change, $\Delta G^{\circ}$, suggest that the adsorption processes were spontaneous. The $\Delta G^{\circ}$ values shifted to lower negative values with an increase in temperature, indicating the instability of the adsorption process at higher temperature. It was also observed that $\Delta G^{\circ}$ values shifted to high positive values at higher concentrations of $\mathrm{As}(\mathrm{III})$ and $\mathrm{As}(\mathrm{V})$ solutions, indicating that the spontaneity of the adsorption process was disturbed. It may be thus concluded that the uptake of $\mathrm{As}(\mathrm{III})$ and $\mathrm{As}(\mathrm{V})$ by PLP remained thermodynamically favorable only at room temperature and at lower arsenic concentrations. It has been shown that at high temperatures, unstable complexes are formed between arsenite or arsenate species and the adsorbent surface without any kind of electrostatic attraction [39]. The anions might have escaped from the adsorbent surface to the bulk of the solution at higher temperatures, or alternatively, the pores on the PLP surface might have opened up at a higher temperature, releasing $\mathrm{As}(\mathrm{III})$ or $\mathrm{As}(\mathrm{V})$ anions back to the solution [66].

\section{Conclusion}

This work shows that a cellulosic biosorbent, PLP, can be successfully utilized for removal of both trivalent and pentavalent arsenic from water at concentrations in which the problem of arsenic contamination is found in different 
Table 5 Langmuir monolayer capacity of biosorbents

\begin{tabular}{|c|c|c|c|c|}
\hline \multirow[t]{2}{*}{ Adsorbents } & \multicolumn{2}{|c|}{$q_{m}\left(\mathrm{mg} \mathrm{g}^{-1}\right)$} & \multirow[t]{2}{*}{ Temperature $(K)$} & \multirow[t]{2}{*}{ References } \\
\hline & As(III) & $\mathrm{As}(\mathrm{V})$ & & \\
\hline Shelled Moringa oleifera Lamarck seeds & 1.59 & 2.16 & - & 22 \\
\hline Cod fish scales & 0.025 & 0.027 & 303 & 23 \\
\hline \multirow[t]{3}{*}{ Agricultural residue 'rice polish' } & 0.139 & 0.147 & 293 & \multirow[t]{3}{*}{24} \\
\hline & 0.097 & 0.101 & 303 & \\
\hline & 0.064 & 0.068 & 313 & \\
\hline Momordica charantia biomass & 0.88 & - & 301 & 26 \\
\hline Long-root Eichhornia crassipes & 1.17 & 1.78 & 303 & 29 \\
\hline Ceramium ciliatum (red algae) & - & $0.88-1.24$ & - & 31 \\
\hline Gracilaria bursa-pastoris (red algae) & - & $0.86-0.96$ & & 31 \\
\hline Ulva rigida (green algae) & - & $0.24-0.76$ & & 31 \\
\hline Caulerpa racemosa (green algae) & - & $0.38-0.45$ & & 31 \\
\hline Dictyopteris polypodioides & - & $0.92-1.00$ & & 31 \\
\hline Cystoseira compressa (brown algae) & - & $0.0-0.72$ & & 31 \\
\hline Zostera marina (seagrass) & - & $0.59-0.87$ & & 31 \\
\hline Pine leaves & - & 3.27 & 298 & 32 \\
\hline Palm bark & 1.030 & - & 298 & 33 \\
\hline Saccharum officinarum (sugarcane) bagasse & 1.203 & 2.375 & 298 & 40 \\
\hline Azadirachta indica (neem) bark & 0.167 & - & 303 & 41 \\
\hline Stem of Tecomella undulata & 0.108 & 0.159 & $298-318$ & 54 \\
\hline Saccharomyces cerevisiae & 0.063 & - & 308 & 64 \\
\hline Japanese oak wood-derived biochar & 3.16 & 3.89 & 293 & 65 \\
\hline Polyalthia longifolia leaf powder (PLP) & 1.76 & 1.87 & 303 & Present study \\
\hline
\end{tabular}

Table 6 Thermodynamic parameters for adsorption of $\mathrm{As}(\mathrm{III})$ and $\mathrm{As}(\mathrm{V})$ onto PLP

\begin{tabular}{|c|c|c|c|c|c|}
\hline \multirow[t]{2}{*}{$\mathrm{As}$ (III) conc. $\left(\mathrm{mg} \mathrm{L}^{-1}\right)$} & \multirow[t]{2}{*}{$\Delta H_{\mathrm{av}}^{\circ}\left(\mathrm{kJ} \mathrm{mol}{ }^{-1}\right)$} & \multirow[t]{2}{*}{$\Delta S^{\circ}{ }_{\text {av }}\left(\mathrm{J} \mathrm{mol}^{-1} \mathrm{~K}^{-1}\right)$} & \multicolumn{3}{|c|}{$\Delta G^{\circ}\left(\mathrm{kJ} \mathrm{mol}{ }^{-1}\right)$} \\
\hline & & & $303 \mathrm{~K}$ & $313 \mathrm{~K}$ & $323 \mathrm{~K}$ \\
\hline 0.5 & -12.26 & -34.52 & -1.90 & -1.41 & -1.18 \\
\hline 1.0 & -17.79 & -52.87 & -1.81 & -1.23 & -0.71 \\
\hline 1.5 & -20.46 & -62.49 & -1.60 & -0.85 & -0.30 \\
\hline 2.0 & -16.79 & -51.05 & -1.18 & -0.87 & -0.13 \\
\hline 2.5 & -12.49 & -39.24 & -0.71 & -0.16 & 0.10 \\
\hline 3.0 & -9.12 & -30.83 & -0.08 & 0.69 & 0.56 \\
\hline 4.0 & -5.71 & -20.64 & 0.52 & 0.76 & 0.95 \\
\hline 5.0 & -15.69 & -54.73 & 0.78 & 1.50 & 1.91 \\
\hline \multirow[t]{2}{*}{$\mathrm{As}(\mathrm{V})$ conc. $\left(\mathrm{mg} \mathrm{L}^{-1}\right)$} & \multirow[t]{2}{*}{$\Delta H_{\mathrm{av}}^{\circ}\left(\mathrm{kJ} \mathrm{mol}{ }^{-1}\right)$} & \multirow[t]{2}{*}{$\Delta S^{\circ}{ }_{\mathrm{av}}\left(\mathrm{J} \mathrm{mol}^{-1} \mathrm{~K}^{-1}\right)$} & \multicolumn{3}{|c|}{$\Delta G^{\circ}\left(\mathrm{kJ} \mathrm{mol}{ }^{-1}\right)$} \\
\hline & & & $303 \mathrm{~K}$ & $313 \mathrm{~K}$ & $323 \mathrm{~K}$ \\
\hline 0.5 & -9.20 & -22.16 & -2.43 & -2.30 & -1.97 \\
\hline 1.0 & -8.82 & -22.54 & -1.94 & -1.80 & -1.47 \\
\hline 1.5 & -6.75 & -17.20 & -1.54 & -1.38 & -1.18 \\
\hline 2.0 & -4.94 & -13.27 & -0.96 & -0.78 & -0.68 \\
\hline 2.5 & -3.44 & -9.62 & -0.55 & -0.42 & -0.35 \\
\hline 3.0 & -10.19 & -33.26 & -0.25 & 0.30 & 0.43 \\
\hline 4.0 & -5.59 & -18.92 & 0.19 & 0.31 & 0.58 \\
\hline 5.0 & -9.01 & -31.27 & 0.52 & 0.74 & 1.16 \\
\hline
\end{tabular}


parts of the world. The adsorption process is rapid and reaches equilibrium in a comparatively short time interval. Pseudo-second-order kinetics of the adsorption process shows that arsenic may bond to two similar or dissimilar sites on the adsorbent surface. While surface adsorption is likely to be the major mechanism of arsenic uptake, some amount may be held through intraparticle diffusion. The maximum adsorption capacity of Polyalthia longifolia leaf powder (PLP) was found to be $1.76 \mathrm{mg} \mathrm{g}^{-1}\left(\mathrm{As}^{3+}\right)$ and $1.87 \mathrm{mg} \mathrm{g}^{-1}\left(\mathrm{As}^{5+}\right)$, which is better than similar biosorbents. Although the adsorption capacity is low when compared to that of commercial adsorbents, the low cost and ecofriendly nature of the biosorbent makes it attractive for tackling the problem of arsenic contamination in developing countries. The process is thermodynamically spontaneous, works at around room temperature, and is simple, without the need for complex technical know-how. That arsenic can be removed in both a single and binary solute systems confirms that surface adsorption is the major mechanism for arsenite or arsenate removal.

Acknowledgements The authors gratefully acknowledge Prof. D.K. Kakati, Head, Department of Chemistry, Gauhati University, Guwahati, for providing SEM-EDX (scanning electron microscope and energy dispersive X-ray analyzer) instrument facilities and other necessary facilities.

\section{Compliance with ethical standards}

Conflict of interest The authors declare that they have no competing interests.

\section{References}

1. USEPA (US. Environmental Protection Agency) (1997) IRIS (Integrated Risk Information System) On-line Database Maintained in Toxicology Data Network (TOXNET) by the National Library of Medicine. USEPA, Bethesda, MD. https://cfpub.epa.gov/ncea/ iris2/chemicalLanding.cfm?\&substance_nmbr=278. Accessed 8 Apr 2020

2. Flanagan SV, Johnston RB, Zheng Y (2012) Arsenic in tube well water in Bangladesh: health and economic impacts and implications for arsenic mitigation. B World Health Organ 90:839-854

3. Saha D, Sahu S (2016) A decade of investigations on groundwater arsenic contamination in Middle Ganga Plain. India, Environ Geochem Health 38:315-337

4. Ansone L, Klavins M, Viksna A (2013) Arsenic removal using natural biomaterial-based sorbents. Environ Geochem Health 35:633-642

5. Cardenas-Gonzalez JF, Acosta-Rodriguez I, Teran-Figueroa $Y$, Rodriguez-Perez AS (2017) Bioremoval of arsenic (V) from aqueous solutions by chemically modified fungal biomass. 3 Biotech 7:226-232

6. Jain CK, Ali I (2000) Arsenic: occurrence, toxicity and speciation techniques. Water Res 34:4304-4312

7. Sun HJ, Rathinasabapathi B, Wu B, Luo J, Pu LP, Ma LQ (2014) Arsenic and selenium toxicity and their interactive effects in humans. Environ Int 69:148-158
8. Mandal BK, Ogra Y, Suzuki KT (2003) Speciation of arsenic in human nail and hair from arsenic-affected area by HPLC inductively coupled argon plasma mass spectrometry. Toxicol Appl Pharmacol 189:73-83

9. Villaescusa I, Bollinger JC (2008) Arsenic in drinking water: sources, occurrence, and health effects (a review). Rev Environ Sci Biotechnol 7:307-323

10. Concha G, Vogler G, Lezcano D, Nermell B, Vahter M (1998) Exposure to inorganic arsenic metabolites during early human development. Toxicol Sci 44:185-190

11. Concha G, Vogler G, Nermell B, Vahter M (1998) Low-level arsenic excretion in breast milk of native Andean women exposed to high levels of arsenic in the drinking water. Int Arch Occup Environ Health 71:42-46

12. WHO (2001) Arsenic Compounds, Environmental Health Criteria 224, 2nd ed., World Health Organisation, Geneva. https ://www.who.int/ipcs/publications/ehc/ehc_224/en. Accessed 8 Apr 2020

13. US EPA (2009) National Primary Drinking Water Regulations. US Environmental Protection Agency. EPA 816-F-09-004. https ://www.epa.gov/ground-water-and-drinking-water/nationalprimary-drinking-water-regulation-table. Accessed 8 Apr 2020

14. Chiban M, Zerbet M, Carja G, Sinan F (2012) Application of low-cost adsorbents for arsenic removal: a review. J Environ Chem Ecotoxicol 4:91-102

15. Trinh VT, Nguyen TMP, Van HT, Hoang LP, Nguyen TV, Ha LT, Vu XH, Pham TT, Nguyen TN, Quang NV, Nguyen XC (2020) Phosphate adsorption by silver nanoparticles-loaded activated carbon derived from tea residue. Sci Rep 10:3634. https://doi. org/10.1038/s41598-020-60542-0

16. Nguyen LH, Nguyen TMP, Van HT, Vu XH, Ha TLA, Nguyen THV, Nguyen XH, Nguyen XC (2019) Treatment of hexavalent chromium contaminated wastewater using activated carbon derived from coconut shell loaded by silver nanoparticles: batch experiment. Water Air Soil Pollut 230:68. https://doi. org/10.1007/s11270-019-4119-8

17. Hoang $L P$, Van $H T$, Nguyen $L H, M a c D H, V u T T, H a L T$, Nguyen XC (2019) Removal of $\mathrm{Cr}(\mathrm{VI})$ from aqueous solution using magnetic modified biochar derived from raw corncob. New J Chem 43:18663-18672

18. Van HT, Nguyen TMP, Vu TT, Hoa VX, Nguyen TV, Nguyen LH (2018) Applying activated carbon derived from coconut shell loaded by silver nanoparticles to remove methylene blue in aqueous solution. Water Air Soil Pollut 229:393. https://doi. org/10.1007/s11270-018-4043-3

19. Wan Ngah WS, Teong LC, Hanafiah MAKM (2011) Adsorption of dyes and heavy metal ions by chitosan composites a review. Carbohyd Polym 83:1446-1456

20. Luo X, Wang C, Wang L, Deng F, Luo S, Tu X, Au C (2013) Nanocomposites of graphene oxide-hydrated zirconium oxide for simultaneous removal of $\mathrm{As}(\mathrm{III})$ and $\mathrm{As}(\mathrm{V})$ from water. Chem Eng J 220:98-106

21. Giri AK, Patel RK, Mahapatra SS, Mishra PC (2013) Biosorption of arsenic(III) from aqueous solution by living cells of Bacillus cereus. Environ Sci Pollut Res 20:1281-1291

22. Kumari P, Sharma P, Srivastava S, Srivastava MM (2006) Biosorption studies on shelled Moringa oleifera Lamarck seed powder: Removal and recovery of arsenic from aqueous system. Int J Miner Process 78:131-139

23. Rahaman MS, Basu A, Islam MR (2008) The removal of As(III) and $\mathrm{As}(\mathrm{V})$ from aqueous solutions by waste materials. Bioresour Technol 99:2815-2823

24. Ranjan D, Talat M, Hasan SH (2009) Biosorption of arsenic from aqueous solution using agricultural residue 'rice polish'. J Hazard Mater 166:1050-1059 
25. Tuzen M, Sari A, Mendil D, Uluozlu OD, Soylak M, Dogan M (2009) Characterization of biosorption process of $\mathrm{As}$ (III) on green algae Ulothrix cylindricum. J Hazard Mater 165:566-572

26. Pandey PK, Choubey S, Verma Y, Pandey M, Chandrashekhar K (2009) Biosorptive removal of arsenic from drinking water. Bioresour Technol 100:634-637

27. Sari A, Tuzen M (2010) Biosorption of $A s(I I I)$ and $A s(V)$ from aqueous solution by lichen (Xanthoria parietina) biomass. Sep Sci Technol 45:463-471

28. Sari A, Uluozlu OD, Tuzen M (2011) Equilibrium, thermodynamic and kinetic investigations on biosorption of arsenic from aqueous solution by algae (Maugeotia genuflexa) biomass. Chem Eng J 167:155-161

29. Lin S, Wang G, Na Z, Lu D, Liu Z (2012) Long-root Eichhornia crassipes as a biodegradable adsorbent for aqueous $\mathrm{As}(\mathrm{III})$ and As(V). Chem Eng J 183:365-371

30. Baig JA, Kazi TG, Elci L (2012) Biosorption characteristics of indigenous plant material for trivalent arsenic removal from groundwater: equilibrium and kinetic studies. Sep Sci Technol 47:1044-1054

31. Pennesi C, Vegliò F, Totti C, Romagnoli T, Beolchini F (2012) Nonliving biomass of marine macrophytes as arsenic $(\mathrm{V})$ biosorbents. J Appl Phycol 24:1495-1502

32. Shafique U, ljaz A, Salman M, Zaman WU, Jamil N, Rehman R, Javaid A (2012) Removal of arsenic from water using pine leaves. J Taiwan Inst Chem Eng 43:256-263

33. Kamsonlian S, Suresh S, Majumder CB, Chand S (2012) Biosorption of $\mathrm{As}$ (III) from contaminated water onto low cost palm bark biomass. Int J Curr Eng Technol 2:153-158

34. Nigam S, Gopal K, Vankar PS (2013) Biosorption of arsenic in drinking water by submerged plant: Hydrilla verticilata. Environ Sci Pollut Res 20:4000-4008

35. Nigam S, Vankar PS, Gopal K (2013) Biosorption of arsenic from aqueous solution using dye waste. Environ Sci Pollut Res 20:1161-1172

36. Raj KR, Kardam A, Srivastava S (2013) Development of polyethylenimine modified Zea mays as a high capacity biosorbent for the removal of As (III) and As (V) from aqueous system. Int J Miner Process 122:66-70

37. Raj KR, Kardam A, Arora JK, Srivastava S (2013) An application of ANN modeling on the biosorption of arsenic. Waste Biomass Valoriz 4:401-407

38. Prasad KS, Ramanathan AL, Paul J, Subramanian V, Prasad R (2013) Biosorption of arsenite $\left(\mathrm{As}^{+3}\right)$ and arsenate $\left(\mathrm{As}^{+5}\right)$ from aqueous solution by Arthrobacter sp. Biomass Environ Technol 34:2701-2708

39. Yu X, Tong S, Ge M, Wu L, Zuo J, Cao C, Song W (2013) Synthesis and characterization of multi-amino-functionalized cellulose for arsenic adsorption. Carbohyd Polym 92:380-387

40. Gupta A, Vidyarthi SR, Sankararamakrishnan N (2015) Concurrent removal of $\mathrm{As}(\mathrm{III})$ and $\mathrm{As}(\mathrm{V})$ using green low cost functionalized biosorbent-Saccharum officinarum bagasse. J Environ Chem Eng 3:113-121

41. Roy P, Dey U, Chattoraj S, Mukhopadhyay D, Mondal NK (2017) Modeling of the adsorptive removal of arsenic(III) using plant biomass: a bioremedial approach. Appl Water Sci 7:1307-1321

42. Habibi Y, Lucia LA, Rojas OJ (2010) Cellulose nanocrystals: chemistry, self assembly and applications. Chem Rev 110:3479-3500

43. Chang FR, Hwang TL, Yang YL, Li CE, Wu CC, Issa HH (2006) Antiinflammatory and cytotoxic diterpenes from formosan Polyalthia longifolia var. pendula. Planta Med 72:1344-1347

44. Chen CY, Chang FR, Shih YC, Hsieh TJ, Chia YC, Tseng HY (2000) Cytotoxic constituents of Polyalthia longifolia var. pendula. J Nat Prod 63:1475-1478

45. Faizi S, Khan RA, Mughal NR, Malik MS, Sajjadi KE, Ahmad A (2008) Antimicrobial activity of various parts of Polyalthia longifolia var. pendula: isolation of active principles from the leaves and the berries. Phytother Res 22:907-912

46. Marthanda MM, Subramanyam M, Hima BM, Annapurna J (2005) Antimicrobial activity of clerodane diterpenoids from Polyalthia longifolia seeds. Fitoterapia 76:336-339

47. Tanna A, Nair R, Chanda S (2009) Assessment of anti-inflammatory and hepatoprotective potency of Polyalthia longifolia var. pendula leaf in wistar albino rats. J Nat Med 63:80-85

48. Zhau G, Jung JH, Smit DL, Wood KV, Laughlin MC (1991) Cytotoxic clerodane diterpenes from Polyalthia longifolia. Planta Med 57:380-383

49. Chattoraj S, Mondal NK, Das B, Roy P, Sadhukhan B (2014) Biosorption of carbaryl from aqueous solution onto Pistia stratiotes biomass. Appl Water Sci 4:79-88

50. Bektaş N, Aydın S, Öncel MS (2011) The adsorption of arsenic ions using beidellite, zeolite and sepiolite clays: a study of kinetic, equilibrium and thermodynamics. Separ Sci Technol 46:1005-1016

51. Borah D, Satokawa S, Kato S, Kojima T (2009) Sorption of As(V) from aqueous solution using acid modified carbon black. J Hazard Mater 162:1269-1277

52. Amin MT, Alazba AA, Amin MN (2017) Absorption behaviours of copper, lead, and arsenic in aqueous solution using date palm fibres and orange peel: kinetics and thermodynamics. Pol J Environ Stud 26:543-557

53. Podder MS, Majumder CB (2017) Biosorption of As(III) and $\mathrm{As}(\mathrm{V})$ on the surface of TW/MnFe $\mathrm{O}_{4}$ composite from wastewater: kinetics, mechanistic and thermodynamics. Appl Water Sci 7:2689-2715

54. Brahman KD, Kazi TG, Baig JA, Afridi HI, Arain SS, Saraj S, Arain MB, Arain SA (2016) Biosorptive removal of inorganic arsenic species and fluoride from aqueous medium by the stem of Tecomella undulate. Chemosphere 150:320-328

55. Rajesh Kannan R, Rajasimman M, Rajamohan N, Sivaprakash B (2010) Equilibrium and kinetic studies on sorption of malachite green using Hydrilla verticillata biomass. Int J Environ Res 4:817-824

56. Schiewer S, Patil SB (2008) Pectin-rich fruit wastes as biosorbents for heavy metal removal: equilibrium and kinetics. Bioresour Technol 99:1896-1903

57. Glocheux Y, Pasarín MM, Albadarin AB, Allen SJ, Walker GM (2013) Removal of arsenic from groundwater by adsorption onto an acidified laterite by-product. Chem Eng J 228:565-574

58. Baig JA, Kazi TG, Shah AQ, Kandhro GA, Afridi HI, Khan S, Kolachi NF (2010) Biosorption studies on powder of stem of Acacia nilotica: Removal of arsenic from surface water. J Hazard Mater 178:941-948

59. Wu F, Tseng R, Juang R (2009) Initial behavior of intraparticle diffusion model used in the description of adsorption kinetics. Chem Eng J 153:1-8

60. Samaraweera APGMV, Priyantha N, Gunathilake WSS, Kotabewatta PA, Kulasooriya TPK (2020) Biosorption of $\mathrm{Cr}$ (III) and $\mathrm{Cr}(\mathrm{VI})$ species on $\mathrm{NaOH}$-modified peel of Artocarpus nobilis fruit. 1. Investigation of kinetics. Appl Water Sci 10:115. https ://doi.org/10.1007/s13201-020-01187-2

61. Das B, Mondal NK, Bhaumik R, Roy P (2014) Insight into adsorption equilibrium, kinetics and thermodynamics of lead onto alluvial soil. Int J Environ Sci Technol 11:1101-1114

62. Su C, Puls RW (2001) Arsenate and arsenite removal by zerovalent iron: Effects of phosphate, silicate, carbonate, borate, sulfate, chromate, molybdate and nitrate, relative to chloride. Environ Sci Technol 35:4562-4568

63. Wu Y, Wen Y, Zhou J, Dai Q, Wu Y (2012) The characteristics of waste Saccharomyces cerevisiae biosorption of arsenic(III). Environ Sci Pollut Res 19:3371-3379 
64. Niazi NK, Bibi I, Shahid M, Ok YS, Shaheen SM, Rinklebe J, Lüttge A (2018) Arsenic removal by Japanese oak wood biochar in aqueous solutions and well water: investigating arsenic fate using integrated spectroscopic and microscopic techniques. Sci Total Environ 621:1642-1651

65. Prasad KS, Srivastava P, Subramanian V, Paul J (2011) Biosorption of As(III) ion on Rhodococcus sp. WB-12: biomass characterization and kinetic studies. Sep Sci Technol 46:2517-2525

66. Bhattacharyya KG, Sharma A (2004) Azadirachta indica leaf powder as an effective biosorbent for dyes: a case study with aqueous congo red solutions. J Environ Manag 71:217-229
Publisher's Note Springer Nature remains neutral with regard to jurisdictional claims in published maps and institutional affiliations. 